\title{
Challenges and Responses to Ongoing and Projected Climate Change for Dryland Cereal Production Systems throughout the World
}

\author{
Garry J. O'Leary ${ }^{1, *}$, Pramod K. Aggarwal ${ }^{2}$, Daniel F. Calderini ${ }^{3}$, David J. Connor ${ }^{4}$, \\ Peter Craufurd ${ }^{5}$, Sanford D. Eigenbrode ${ }^{6}$, Xue Han ${ }^{7}$ and Jerry L. Hatfield ${ }^{8}$
}

1 Agriculture Victoria Research, Department of Economic Development, Jobs, Transport and Resources, Horsham, Victoria 3400, Australia

2 CGIAR Research Program on Climate Change, Agriculture and Food Security (CCAFS),

Borlaug Institute for South Asia (BISA), International Maize and Wheat Improvement Center (CIMMYT), NASC Complex, New Delhi 110012, India; p.k.aggarwal@cgiar.org

3 Institute of Plant Production and Protection, Universidad Austral de Chile, Campus Isla Teja, Valdivia 14101, Chile; danielcalderini@uach.cl

4 Faculty of Veterinary and Agricultural Sciences, The University of Melbourne, Melbourne, Victoria 3010, Australia; djconnor@unimelb.edu.au

5 International Maize and Wheat Improvement Center, ICRAF House, United Nations Avenue, Nairobi 00601, Kenya; p.craufurd@cgiar.org

6 Department of Entomology, Plant Pathology and Nematology, University of Idaho, Moscow, ID 83209, USA; sanforde@uidaho.edu

7 Institute of Environment and sustainable Development in Agriculture/Key Laboratory of Ministry of Agriculture on Agro-Environment and Climate Change, Chinese Academy of Agricultural Sciences, Beijing 100081, China; hanxue@caas.cn

8 Laboratory Director and Supervisory Plant Physiologist, National Laboratory for Agriculture and the Environment, Ames, IA 50011, USA; jerry.hatfield@ars.usda.gov

* Correspondence: garry.oleary@ecodev.vic.gov.au or gjoleary@yahoo.com; Tel.: +61-3-53622111

Received: 28 February 2018; Accepted: 16 March 2018; Published: 23 March 2018

\begin{abstract}
Since the introduction of mechanized production in both developed and developing countries, crops and their management have undergone significant adaptation resulting in increased productivity. Historical yield increases in wheat have occurred across most regions of the world (20-88 $\mathrm{kg} \mathrm{ha}^{-1}$ year $^{-1}$ ), but climate trends threaten to dampen or reverse these gains such that yields are expected to decrease by $5-6 \%$ despite rising atmospheric $\mathrm{CO}_{2}$ concentrations. Current and projected climatic factors are temporally and spatially variable in dryland cereal production systems throughout the world. Productivity gains in wheat in some locations have been achieved from traditional agronomic practices and breeding. Continued improvement in all cereal production regions and locations of the world requires technical advances, including closer monitoring of soils, water conservation strategies, and multiple sowing times using different crops to reduce risks. The management of disease, pests, and weeds will be an added challenge, especially in areas of higher precipitation. Excellent progress has been achieved in Asia and there is much potential in Sub-Saharan Africa. Technical solutions seem within our grasp but must be implemented in the context of variable social, economic, regulatory, and administrative constraints, providing opportunities for cross fertilization and global collaboration to meet them.
\end{abstract}

Keywords: crop modelling; sustainability; productivity; global production 


\section{Introduction}

Increases in atmospheric $\mathrm{CO}_{2}$ concentrations and accompanying rising temperatures are underway and are generally projected to increase worldwide, but the specific changes will differ widely depending upon latitude, geography, and other factors affecting regional and local climates. Impacts of these changes to various human activities and requisite adaptations to cope with the changes will also differ widely. This is exemplified for wheat and small-grain cereal production worldwide. These crops are principal staples and sources of livelihood for much of the world's population. About one half of global wheat is produced in semi-arid climates from $\left|20^{\circ}\right|$ and $\left|60^{\circ}\right|$ latitude with precipitation between 250 and $450 \mathrm{~mm}$ [1]. Projected climate change and impacts on wheat will differ substantially across these gradients, within and among continents, based on historical yield trends and projections $[2,3]$. In addition, cereal systems range from large-scale mechanized systems to smallholder, subsistence level production. Thus, the technological, agronomic, social, and cultural aspects are diverse. Nonetheless, the need for continual adaptation of these cropping systems to climate change is a common thread that merits a comprehensive comparative assessment.

The notion that cropping systems will need continual adaptation to changes in climate is not new [4], but an appreciation for the complexity of these systems and the combination of approaches needed to address them and their components is required. Two extreme views of the needed response have been proposed. One is that crop adaptation to climate change will occur naturally or autonomously because farmers have always adjusted and must continue to adjust their practices to climates and this has been successfully coupled with responsive science in the 20th century. This view comes from the relatively high rates of yield gains achieved to date from traditional agronomic and breeding activity despite the changing climate [5]. The other view advocates transformational or revolutionary change in agriculture [6,7] with a focus beyond our present farming systems to meet the future demands of greater productivity to feed a more populous world under projected climatic conditions. The former appears reasonable for the short term, since the recent $1 \%$ per year yield gains in wheat globally are close to performance needs for the next 15 years $[1,5,8]$, but this is uncertain and perhaps inadequate beyond 2030. The transformational paradigm is often ideological and lacks specific and rigorous testing [9]. Whatever the paradigm, time to implementation must be sufficiently rapid to meet the pace of changing climates and conditions. The time frame for achieving major improvements in yield in farmer-ready cultivars through classic breeding or genetic engineering has been and will likely remain decades rather than years [10].

Although average yields for wheat $[3,11]$ and presumably other cereals are expected to decline with global warming, the effects will differ among regions, localities, and years. It is therefore important to document the likely climatic changes for individual locations to define the scale of adaptation required. It is also important to develop strategies to exploit the good years as well as adapt to poorer ones because of the importance of climate variability in determining yields $[12,13]$ and the possibility of greater variability in future climates [14-16]. The solution will likely be systems designed that optimize mean performance with resilience to climate variability.

Water shortage and high or low temperatures near flowering are the most limiting factors for wheat and other cereal production in most dryland cereal production areas throughout the world [17]. Where crops completely rely on or benefit from some irrigation, reduced water supplies are expected to focus attention on more efficient management practices [18]. For those areas totally dependent on precipitation, management to maximize water use efficiency derives from understanding transpiration and soil evaporation, the component processes of crop water use $[17,19,20]$, and the need to minimize soil water evaporation and to balance crop fertility to control the seasonal pattern of transpiration. Excessive growth and water use during vegetative stages promoted by high $\mathrm{N}$ availability that can cause yield loss by leaving insufficient water for grain filling (termed "haying off") is a recurring theme in agronomic research of Mediterranean environments [21,22]. Effects of impacts of high and low temperature produce conflicting management practices. For example, in Australia breeding and management have focused strongly on avoidance of frost damage at flowering by 
combining cultivars and sowing times to delay flowering until after late frosts. Frost remains a focus of research in Australia's cropping belt [23] despite the projections of fewer frosts as the climate warms. High temperatures in the form of short heat waves at critical stages near flowering and during the early stages of grain filling are an increasing concern for wheat farmers in India and maize farmers in southern Africa [2,24]. As temperature approaches the absolute biological limit for crop growth [25], it will be more difficult to raise yields even though there remains some scope for adaptation to higher temperatures. In this paper, we provide an assessment of global changes in climate and performance of small-grain cereal systems, primarily wheat systems, drawing upon data and examples from Africa, Australia, China, South Asia, and North and South America. We use historical climate and yield trends and climate and yield projections and apply a systems perspective to highlight common actions needed globally to assist in developing research and extension strategies to adapt to our changing climate.

\section{Historical Changes in Climate and Productivity of Cereal Systems}

\subsection{Climate}

Many studies that have examined the historical trend in climatic variables [26] suffer from the relatively short period that comprehensive records have been kept. Nevertheless, some clear trends have been identified since the early 1980s and continue today. Figure 1 shows an example of spatial and temporal variation seen in the Australian annual national precipitation (Figure 1a) and temperature (Figure 1b) anomalies since 1900. During that time, mean temperature has increased significantly without much change in precipitation.

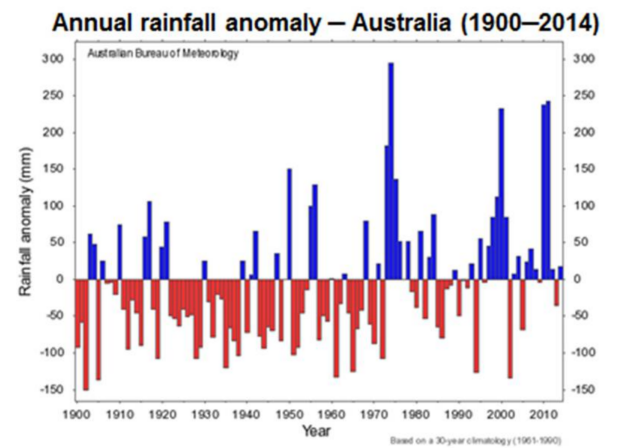

(a)

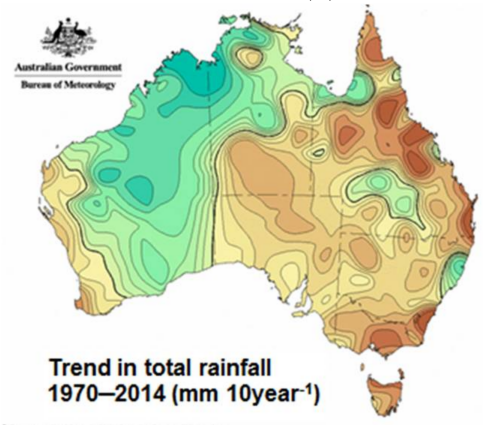

(c)

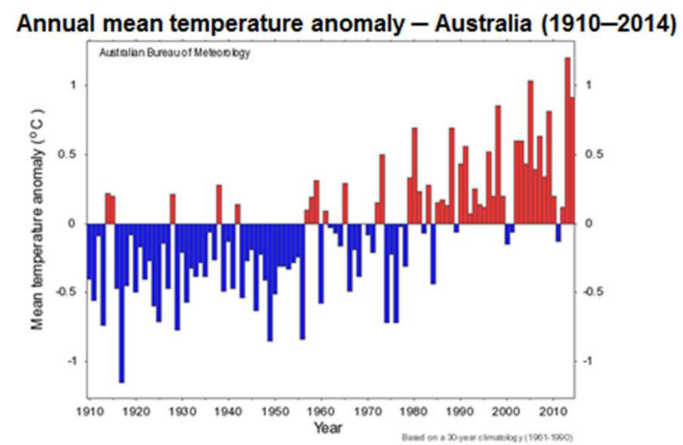

(b)

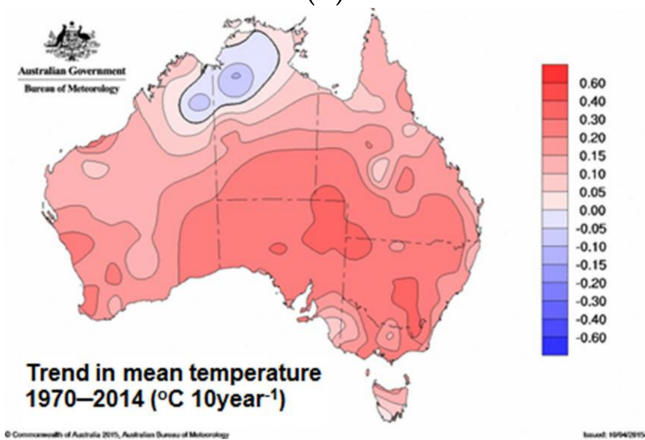

(d)

Figure 1. Long-term annual precipitation (rainfall) (a) and mean temperature (b) anomalies and more recent spatial precipitation (rainfall) (c) and temperature (d) trends over Australia. Source: [27] Bureau of Meteorology, Melbourne, Available online: http:/ / www.bom.gov.au.

There are, however, clear patterns in some parts of Australia in recent years (Figure 1c) with long wet and dry periods associated with the Pacific El-Nino Southern Oscillation (ENSO) [28-30] and higher temperatures in the south-eastern part of Australia (Figure 1d). This significant cause of variability 
(ENSO) has led to many studies evaluating and developing forecasting [31] and management strategies based on short-term climatic forecasts that offer advantage [32], especially in eastern Australia.

Similarly, in China, despite sparse instrumental observations before 1950, well-known long-term data sets of air temperature have been constructed and used to study historical climate change [33-37]. The annual mean air temperature has undergone a warming trend of $0.9-1.5^{\circ} \mathrm{C}$ during the past 100 years (1909-2011) (Figure 2). Although the trend has slowed in the recent 15 years, temperatures are still the warmest during the past century [38]. In contrast, annual average precipitation has not changed throughout China during the past 100 years given the fluctuations between decades and variability. Extreme climate events have occurred more frequently since the 1990s. For example, Southwest China has experienced an unusually protracted and severe drought in the recent 10 years, while the frequency of days of extreme precipitation has increased over the same period in the Yangtze River region and in South China.

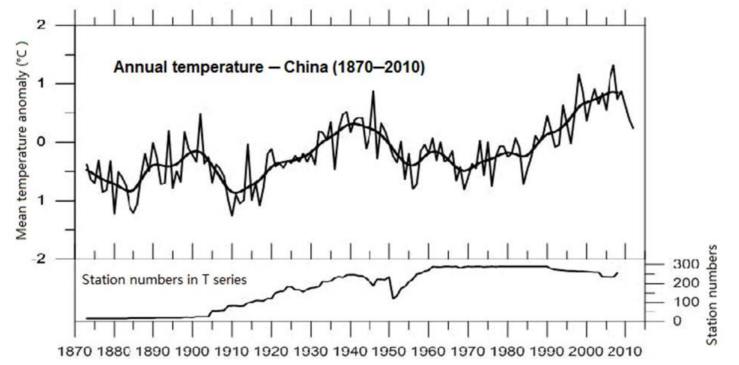

(a)

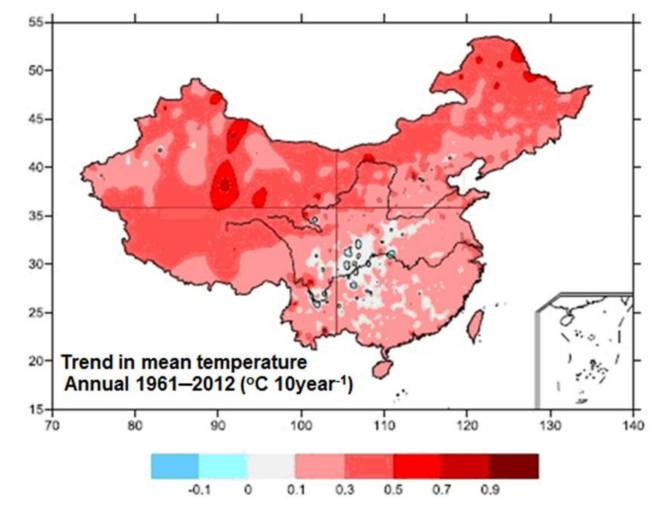

(c)

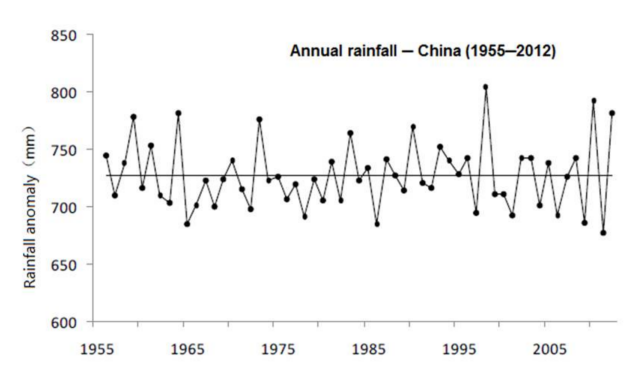

(b)

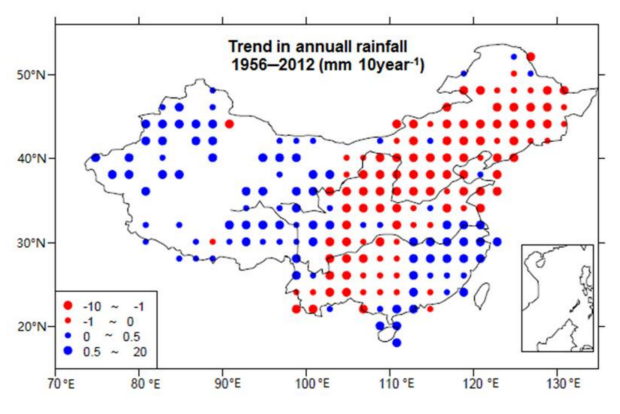

(d)

Figure 2. Long-term mean temperature (a), annual precipitation (rainfall) anomalies (b), and more recent spatial temperature (c) and rainfall trends (d) over China. Source: [38] Committee of Assessment Report of National Climate Change, 2015.

In regions such as south Asia, where the summer monsoon plays an important role, there have always been fluctuations causing dry spells, droughts, waterlogging, and intermittent floods in various parts over time. Several authors have analyzed monsoon frequencies without establishing any consistent trend. For example, no significant effect was discernible in the monsoon volume over India during the last 100 years, although small changes were noticed in some regions [39,40]. Analyses of much shorter time periods, however, show significant decreases in peak-season precipitation and an increase in daily-scale precipitation variability [41]. The Intergovernmental Panel on Climate Change (IPCC) [42] also reports changes in glacier mass and heat events over several Asian regions. Recent studies have shown a trend of increasing temperature over much of India over last 100 years in line with the global observations $[39,40]$.

Africa has much sparser and often incomplete long-term observations of climate as well as extremely diverse production environments [43]. Nonetheless, the IPCC concludes that it is "Very likely 
that mean annual temperature has increased over the past century" [44]. Changes in precipitation are more uncertain because of the sparseness of gauges, but there are sufficient data to conclude "very likely decreases in annual precipitation over the past century over parts of the western and eastern Sahel region of northern Africa, along with very likely increases over parts of eastern and southern Africa" [44]. Despite the uncertain IPCC language, analysis of long-term daily weather records generally supports increases in temperature and changes in precipitation [45].

Changes in climate across the United States have been evaluated recently as part of the National Climate Assessment and demonstrate the regional differences in temperature (Figure 3) and precipitation patterns (Figure 4). Temperature and precipitation have increased along with greater variability among seasons and years. These patterns extend into the Canadian prairies with a warming trend with increased precipitation. These patterns affect productivity of cereal crops with greater impact where temperatures exceed the optimal threshold, but variability of precipitation will remain the main determinant of crop yield.

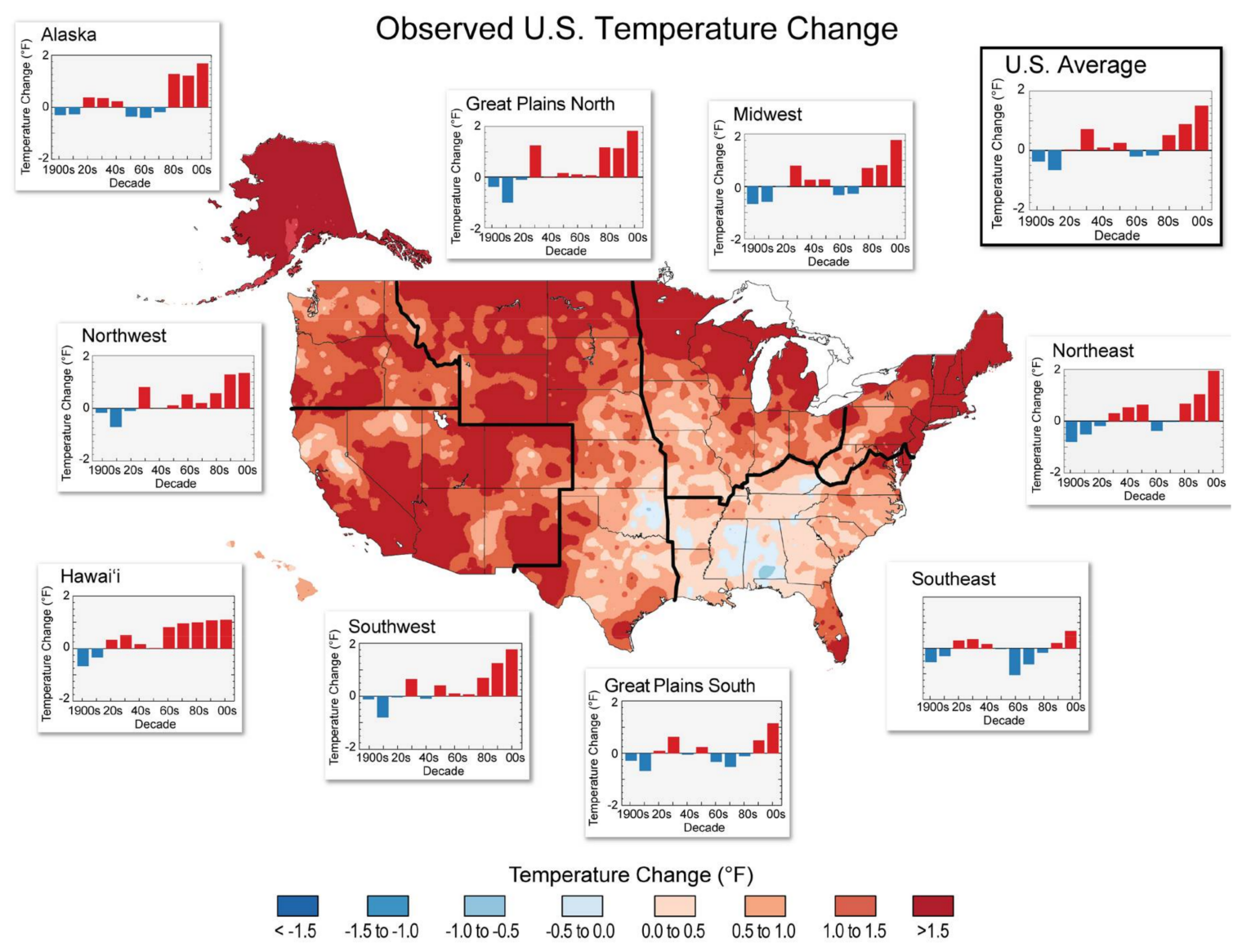

Figure 3. Changes in temperature over the past 22 years (1991-2012) compared to the 1901-1960 average for the continental United States and compared to the 1951-1980 period for Alaska and Hawaii. The bars on graphs show the average temperature change by decade for the 1901-2012 period relative to the 1901-1960 average for each region. The far right bar in each graph (2000s decade) includes 2011 and 2012. The last decade has been the warmest of any during this comparison period. Diagram adapted from the National Oceanic and Atmospheric Administration (NOAA)/National Climatic Data Center (NCDC)/ / Cooperative Institute for Climate and Satellites, North Carolina (CICS-NC). Reprinted with permission from $[46]\left({ }^{\circ} \mathrm{C}=\left({ }^{\circ} \mathrm{F}-32\right) 5 / 9\right)$. 


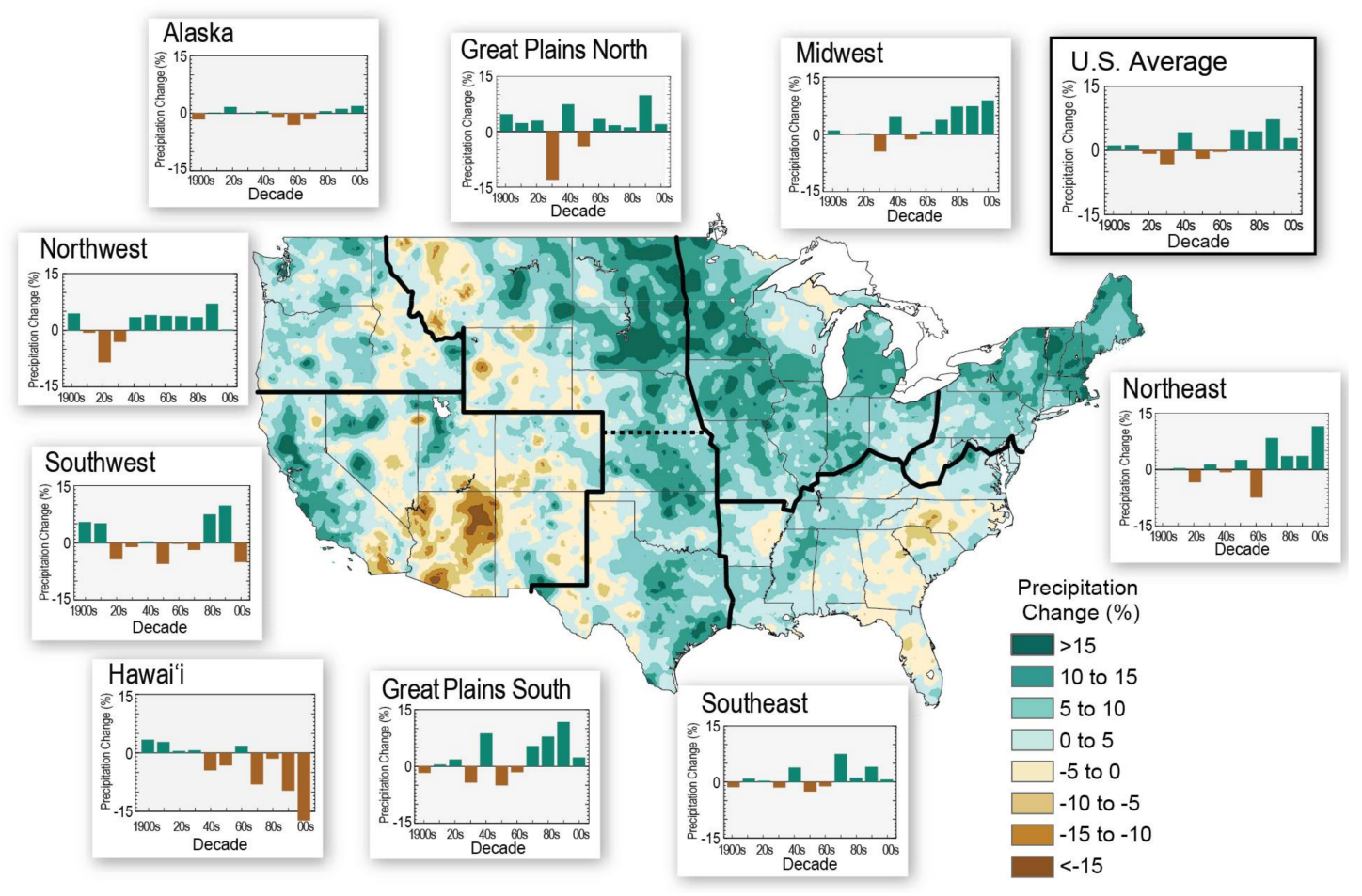

Figure 4. Annual total precipitation for 1991-2012 compared to the 1901-1960 average, showing wetter conditions in most areas. The bars on the graphs show average precipitation differences by decade for 1901-2012 (relative to the 1901-1960 average) for each region. The far right bar in each graph is for 2001-2012. Diagram adapted from NOAA NCDC/CICS-NC. Reprinted with permission from [46].

Climate variability during the last 50 years has been attributed to different causes in different locations across the globe. For example, in South America, the El Niño Southern Oscillation (ENSO), anthropogenic factors such as land use, and global warming have all contributed [47]. Higher temperature has been recorded in the Southeast of South America (East of Argentina, Uruguay, and South of Brazil) during the last 40 years, with a trend of $10-20 \%$ higher minimum temperatures (warmer nights) [48]. Temperatures have also increased in the central Andes of Peru by $0.09{ }^{\circ} \mathrm{C}$ per decade [49] and most Chilean Andes glaciers have reduced in area since the mid-20th century, while on the west coast of South America (Peru and the north of Chile) average temperature has decreased by $1{ }^{\circ} \mathrm{C}$. Other changes have also been recorded in Patagonia of Argentina, although that area is presently very marginal for cereals production.

Precipitation has shown more variability than temperature throughout wheat-producing regions, such as in Australia where precipitation variability is also attributable to the ENSO. Contrasting precipitation trends have been observed in the South Cone of South America. Precipitation has decreased west of the Andes from central to southern Chile but has increased in south eastern South America, with more frequent recent intense precipitation events. For example, the $700 \mathrm{~mm}$ annual isohyet has moved east into previously drier areas of the southwest in Argentina, shifting the boundary between cropping and cattle raising, and imposed new constraints on farming, particularly soil quality.

\subsection{Productivity}

Productivity in Australia has continued to increase from 1900 despite changes to temperature and precipitation. This is seen in Figure 5 for wheat productivity in the State of Victoria. The early yield decline until approximately 1900 reflects a loss of fertility and an increase in root diseases in a system in which wheat was grown continuously without fertilization and with continuing expansion into areas of low precipitation. In contrast, the two subsequent periods of yield gain from 1900 to 
mid-century and mid-century to the present resulted from improved cultivars and management changes that overshadow the small changes in temperature and precipitation. The first management change was the introduction of fallow years and phosphorous fertilizer (1900-1950). The second was the introduction of sequences of wheat with legume pasture ("ley farming") that has been developed further more recently to include a wider range of crops other than cereals (canola, lentil, chickpea, field pea) and the use of $\mathrm{N}$ fertilizer with more efficient and larger machinery that enables better timing of critical farming operations. Breeding of higher-yielding, better-adapted cultivars has been an important feature since 1900. During the hundred years from 1900-2000, the maximum frontier rate of increase was around $20 \mathrm{~kg} \mathrm{ha}^{-1}$ year $^{-1}$. The very-low yields (i.e., 1902, 1914, 1927, 1944, 1967, and 1982) are attributed to seasons of extremely low growing-season precipitation [50]. Two noticeable and important features in the most recent period are the apparent stagnation in yield gain from around 1980 until 2015, and the greater annual variability attributable to precipitation, punctuated by severe droughts. The highest year on record is now 2016 at $3360 \mathrm{~kg} \mathrm{ha}^{-1}$, suggesting a maximum frontier rate of increase of $30 \mathrm{~kg} \mathrm{ha}^{-1}$ year $^{-1}$ since 1950, but results from more years are required to develop a clearer view.

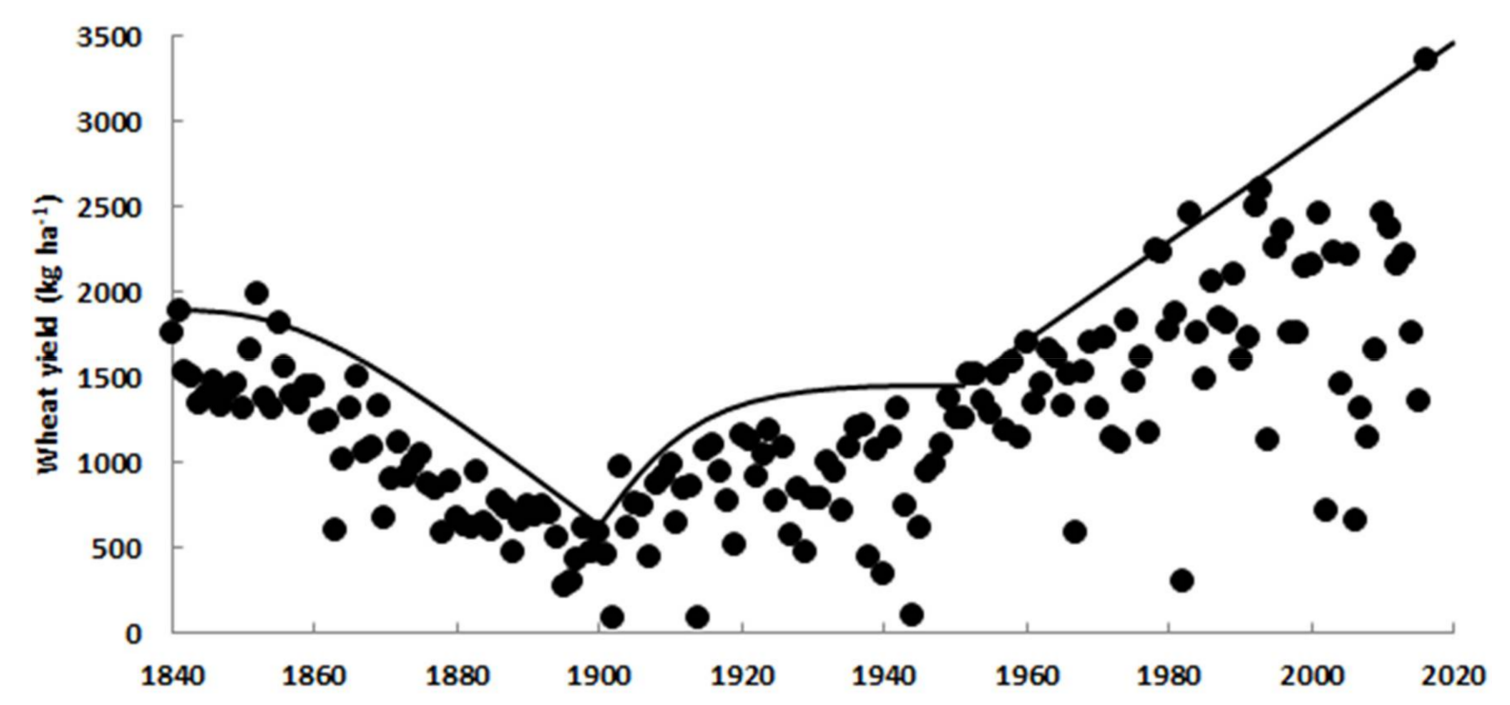

Figure 5. The time course of wheat yield productivity in the State of Victoria, Australia, showing a significant period of declining yield and two subsequent periods of increasing periods that are attributable to genetic and agronomic advances, extended from Connor [51].

In China, historical crop production has shown a strong increase with three distinctive periods from 1961 to 2014 (Figure 6). During 1961-1977, productivity increased despite severe crop losses during the three years of famine (1959-1961) caused by severe drought and changes in agricultural policies. Although grain productivity was 2.5 times greater in 1977 than in 1961, wheat yield was still below $1500 \mathrm{~kg} \mathrm{ha}^{-1}$. From the beginning of the agricultural reforms of 1978, grain productivity grew steadily, reaching a new record of $4102 \mathrm{~kg} \mathrm{ha}^{-1}$ in 1997. But after 1998, Chinese farmers were reluctant to grow grain because of a transitory food surplus and large grain reserves. The result was a rapid decrease in the sown area, with reduced inputs and slowed growth in productivity over five consecutive years (1999-2003) with resultant price hikes beginning in October 2003. To change the situation, the Central Government adopted a series of policies on taxes, land use, and direct subsidies to encourage farmers to plant more grain crops beginning in 2004 . Both yield gain $\left(88 \mathrm{~kg} \mathrm{ha}^{-1} \mathrm{year}^{-1}\right)$ and total production increased and China's grain production reached $607 \mathrm{Mt}$ in 2014, marking an annual increase for 11 consecutive years. This was largely attributed to new and better seeds, expansion of the irrigated area, greater use of fertilizers and mechanization, and the gradual adoption of new agricultural products and technologies [52,53]. Perhaps as a consequence of these increased inputs, the observed warming since 2004 had negligible effects on the major commodities, including wheat [38]. Nonetheless, 
after de-trending for a yield increase attributable to technological improvements, climate trends during 1980-2008 have reduced wheat, maize, and soybean yields by $1.27,1.73$, and $0.41 \%$, respectively, while rice yields have increased by $0.56 \%$ [54].

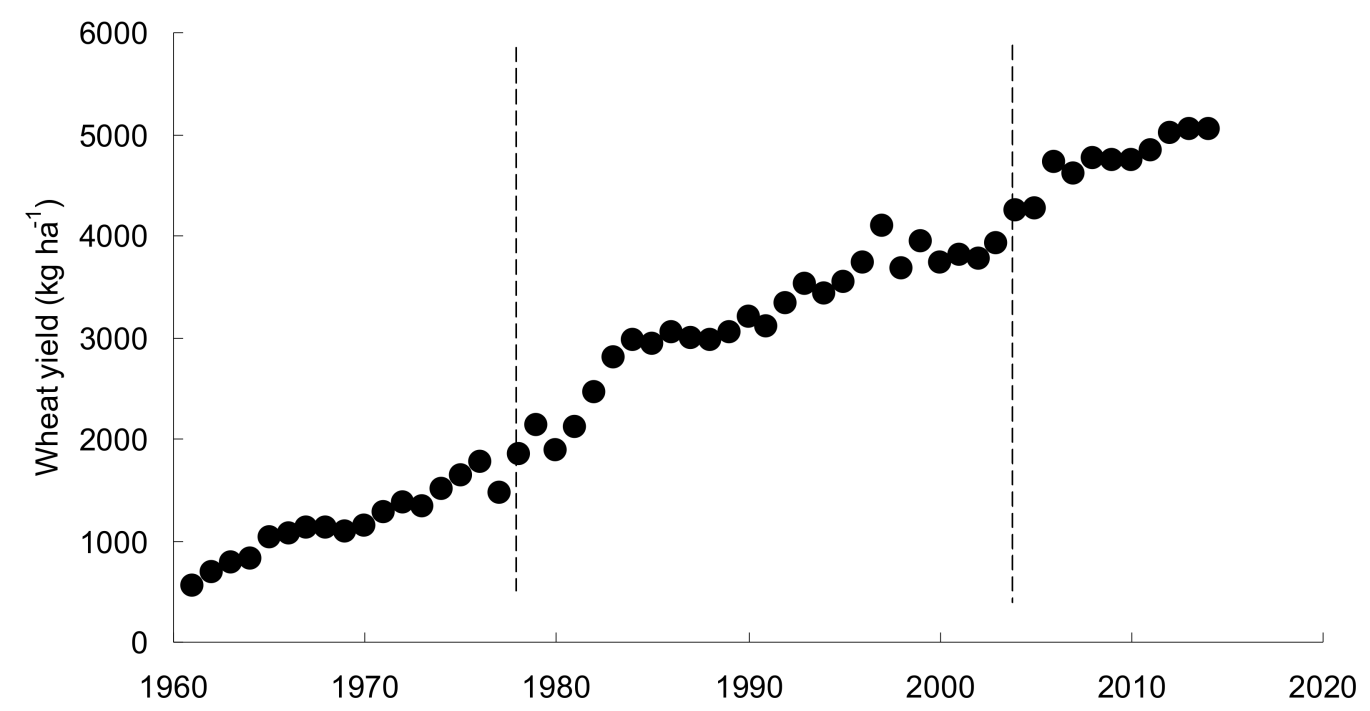

Figure 6. The time course of wheat yield productivity in China showing largely unabated increases (88 $\mathrm{kg} \mathrm{ha}^{-1}$ year $^{-1}$ ) over three distinctive periods from 1961 to 2014. Data source: FAOSTAT [55], (Available online: http:/ / faostat3.fao.org). The first period was before significant agricultural reformation, the second after improvements, and the third after more technological advances, all involving high fertilizer use.

India is the second-largest producer of wheat following China [1]. Its production is largely from the irrigated Punjab region, where farm productivity has been increasing around $30 \mathrm{~kg} \mathrm{ha}^{-1} \mathrm{year}^{-1}$ since 1992, reaching $4.5 \mathrm{t} \mathrm{ha}^{-1}$ by 2011 , and is close to the world average of $1.0 \%$ per annum [1]. In contrast, the productivity of cereals in Africa has stagnated in many countries and overall has not kept pace with demand. Maize rather than wheat is the dominant staple food crop in Africa covering 30 Mha. Maize yields have increased since 1991 by about 12 and $33 \mathrm{~kg} \mathrm{ha}^{-1}$ year $^{-1}$ in East/Central Africa and West Africa, respectively, compared with $142 \mathrm{~kg} \mathrm{ha}^{-1}$ year ${ }^{-1}$ in South Africa. The lower rate in East/Central Africa and West Africa is largely associated with low levels of applied nutrients, $<20 \mathrm{~kg} \mathrm{ha}^{-1}$ fertilizer, on average. There is also significant regional variability reflecting the diverse production environments. Yield increases in sorghum and millet are likewise small, in the order of $<1$ to $2 \%$ year $^{-1}$. However, attainable yields, i.e., yields in well-managed experiments and the best on-farm yields, have increased by 80 to $108 \mathrm{~kg} \mathrm{ha}^{-1}$ year $^{-1}$, suggesting that other factors are limiting productivity gains in Africa [1].

Cereal crop production across North America includes wheat, barley, oats, and rice with wheat being the most widely grown, although the area planted to cereal crops has decreased since 1980 . This decrease is due to shifts in production of other crops, such as soybean, driven by economic pressures and increased incidence of plant disease limiting production. The expanse of wheat production from Mexico to the Canadian prairies encompasses a wide range of climates and production systems. The Pacific Northwest of the United States includes productive non-irrigated and irrigated wheat systems. Productivity of wheat in Mexico (Figure 7), the United States (Figure 8), and Canada (Figure 9) shows similar yield trends and variation among years. Productivity varies within Mexico, but under irrigation or in areas with reliable growing-season precipitation, yields can nearly double the average yields in Canada and the United States. The variation among years is predominantly due to variation in precipitation during the growing season. 


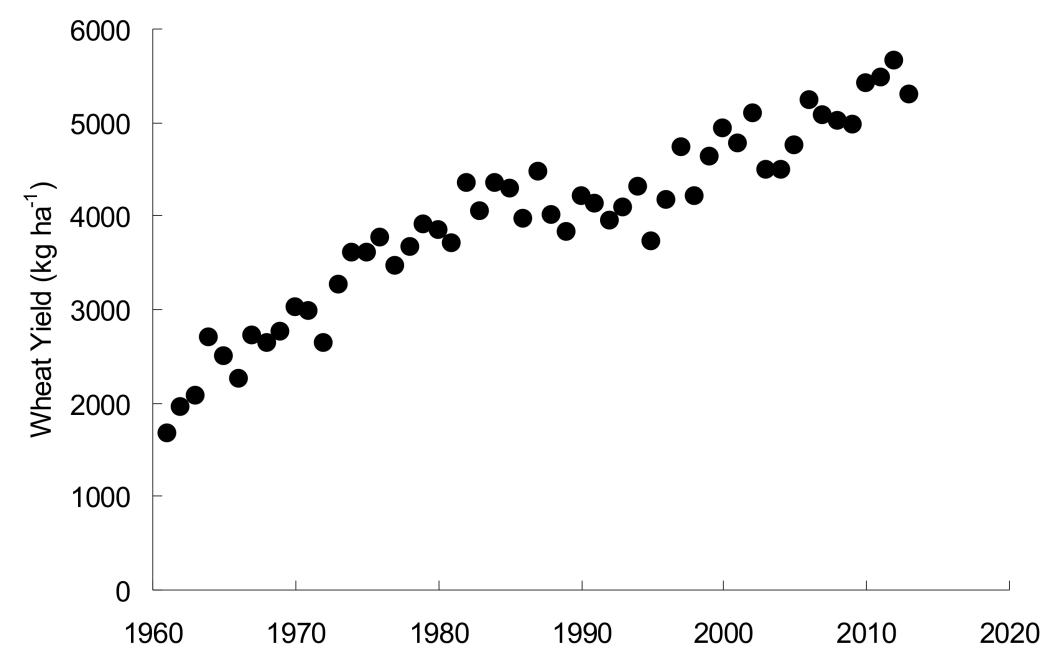

Figure 7. Wheat yield productivity trend in Mexico from 1960 to 2013. The mean yield gain is $59 \mathrm{~kg} \mathrm{ha}^{-1}$ year $^{-1}$, but recent trends from 1990 show a slow down. Data obtained from FAOSTAT [55], http:/ / faostat3.fao.org.

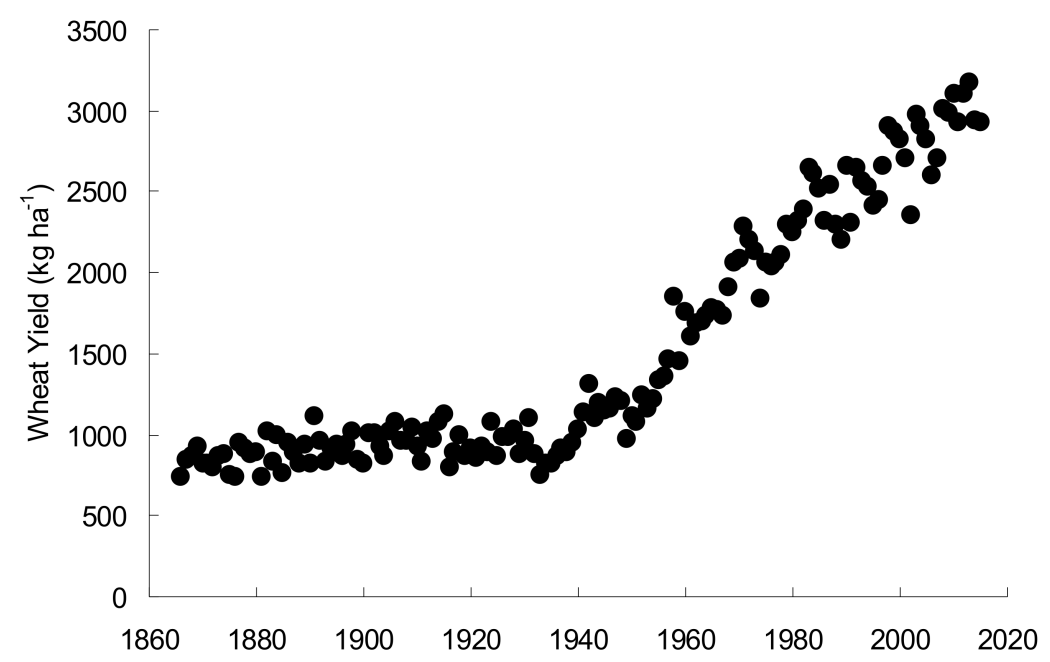

Figure 8. Wheat yield productivity trend in the United States from 1866 to 2015 . The mean yield gain from 1866 to 1940 is $1.3 \mathrm{~kg} \mathrm{ha}^{-1}$ year $^{-1}$ and from 1941 to 2015 is $28 \mathrm{~kg} \mathrm{ha}^{-1}$ year ${ }^{-1}$. Data obtained from the United States Department of Agriculture's National Agricultural Statistics Service [56], Available online: http://www.nass.usda.gov.

The historical trends in crop productivity in various parts of North America show gains over the years despite the negative effects of periodic drought. Where observations have been made since the late 1800s, the distinct advances beginning in the mid-20th century reflect intensified agronomic and breeding efforts to increase productivity (Figures 8 and 9). The widespread availability and use of nitrogen fertilizer drove this revolution and together with the introduction of semi-dwarf wheat in the 1960s propelled the productivity gains to the levels seen today.

In South America, crops other than wheat (e.g., maize, soybean, sunflower) dominate production and the productivity and gains to these major crops are similar to other regions of the world, with Argentina achieving one of the largest gains since 2008-2010 of $176 \mathrm{~kg} \mathrm{ha}^{-1}$ year $^{-1}$ [1]. Argentina is the sixth-largest producer of maize following India, Mexico, Brazil, China, and USA. The primary reasons have been attributed to intensive focus on management practices of reduced or zero tillage as well as breeding efforts [57]. 


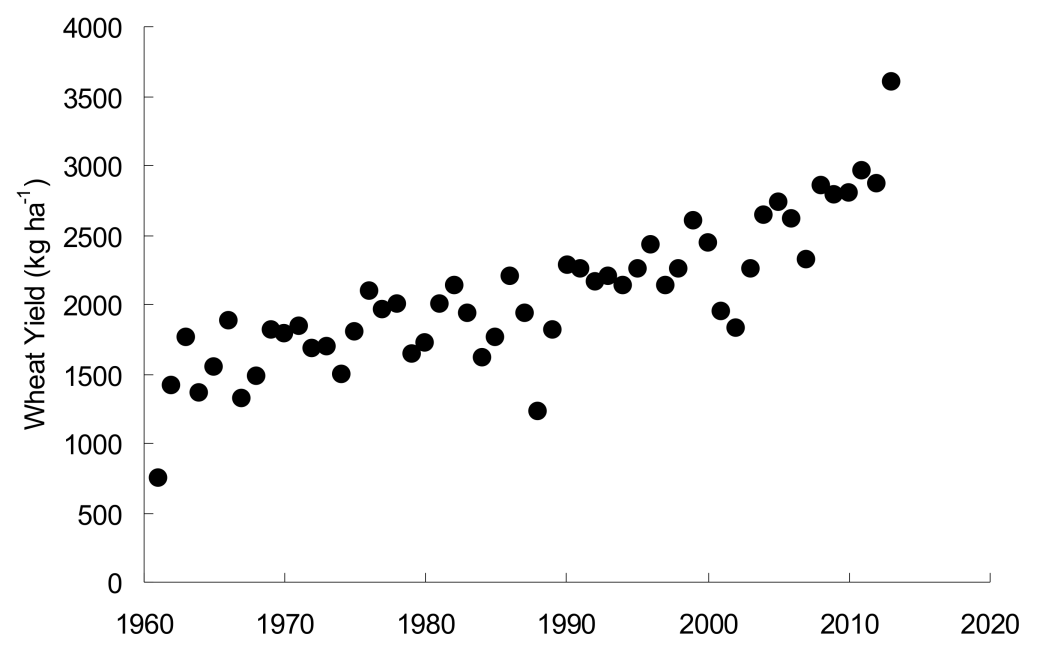

Figure 9. Wheat yield productivity trend in Canada from 1960 to 2013. The mean yield gain is $28 \mathrm{~kg} \mathrm{ha}^{-1}$ year $^{-1}$. Data obtained from FAOSTAT [55], Available online: http:/ / faostat3.fao.org.

\section{Projected Changes in Climate and Cereal Productivity}

\subsection{Climate}

The projected changes in climate around the world are for general increased atmospheric $\mathrm{CO}_{2}$ concentrations and consequent temperatures associated with varied scenarios of less (e.g., Australia) and more (e.g., USA) precipitation. The extent and magnitude of such projections differ around the world, but some examples from Australia, India, Africa, and South America show the general trend, but with variability among locations and regions within continents.

In Australia's southern wheat belt, average temperatures are projected to increase in all seasons. The result will be more hot days and warm spells and fewer frosts. Trends of decreasing winter and spring precipitation are projected, but there is no clear signal with regard to changes to summer and autumn precipitation. Increased intensity of extreme precipitation events is projected [27].

In India, climatic variability and monsoon strength is expected to increase over much of Asia in the 21st century [42]. Seasonal mean precipitation is expected to increase from the East and South Asian monsoons while the change in other monsoon regions is less certain.

Temperature projections for Africa suggest increases ranging from about 2 to $4{ }^{\circ} \mathrm{C}$ for mid-Century, with southern Africa being particularly negatively impacted under the IPCC RCP8 more extreme scenario. Precipitation projections are far more uncertain, but suggest that southern Africa will face declines of up to $20 \%$ while there will be increased precipitation in eastern and West Africa. Maize is particularly vulnerable to high temperature and drought at flowering, and simulations suggest that yield would be reduced by $>20 \%$ for a $1{ }^{\circ} \mathrm{C}$ increase in temperature above $20^{\circ} \mathrm{C}$ under drought [2]. Likewise, other grains, such as millet and sorghum, will be reduced by $10-30 \%$ and variability increased by 2031-2050 [58]. These general effects mask considerable diversity in responses among agro-ecologies or mega-environments, with for example highland systems benefitting from warmer temperatures while both wet and dry lowlands are negatively impacted [59].

Temperature projections for South America and Amazonia forecast increases of $0.6-2{ }^{\circ} \mathrm{C}$ or 3.6-5.2 ${ }^{\circ} \mathrm{C}$ for mid-21st century depending on the scenario (RCP2.6 and RCP8.5, respectively, Figure 10). For late 21st century, increases of $2-4{ }^{\circ} \mathrm{C}$ are projected for the southeast of the subcontinent [60] as well as warmer nights by $6-12 \%$ [61]. While there is less agreement among meteorologists about precipitation projections (Figure 10), increases (of 15-20\%) have been consistently forecasted for Southeast and western Amazonia and the northwest of Peru, while lower precipitation (10-30\%) is projected for the western area of the Andes in Peru and Chile, eastern Amazonia, and northeast and central eastern Brazil. 


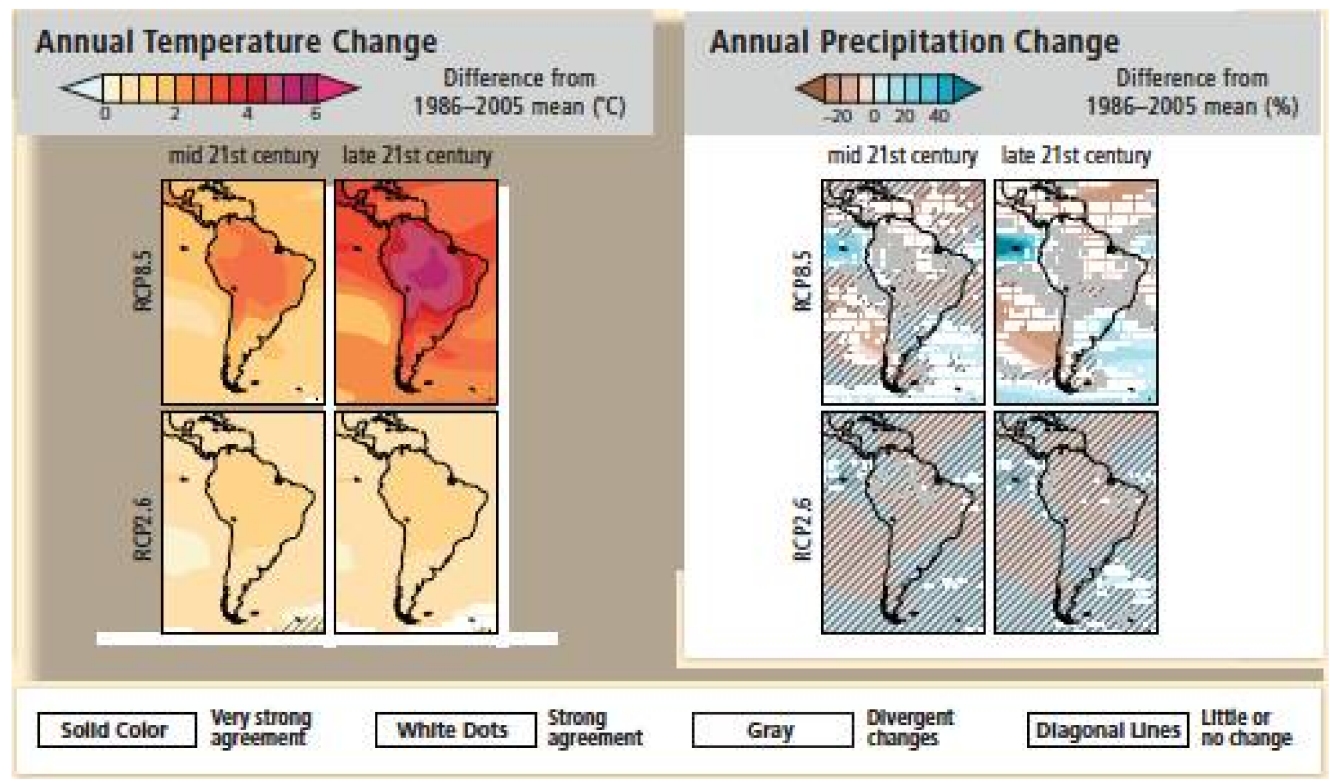

Figure 10. Temperature and precipitation projections for South America showing general increases and decreases in temperature but more uncertainty in rainfall into the future. Source: [47].

\subsection{Cereal Productivity}

Future cereal yields are dependent on temperature and precipitation scenario, the effects of $\mathrm{CO}_{2}$ fertilization, and adapted crop production strategies. Crop models, all with limited skill to predict growth and yield in higher temperature and $\mathrm{CO}_{2}$ concentration than now exist in individual locations where they have been developed, are the only tool with which to make projections. A focus on a single component, such as temperature response, reduces the applicability of current projections.

At the global scale, projected trends of increasing temperatures and elevated $\mathrm{CO}_{2}$ concentrations will have negative impacts on wheat yield globally [3]. In that comparison using 30 different wheat models to simulate wheat productivity, the authors concluded that wheat yields would decrease $6 \%$ per $1{ }^{\circ} \mathrm{C}$ rise in temperature and become more variable in both space and time.

Projections for China made by applying SRES A2 and B2 climate scenarios from PRECIS3 using the CERES crop models suggest that rain-fed wheat, maize, and rice yields in China will decrease on average by $11.4-20.4 \%, 14.5-22.8 \%$, and $8.5-13.6 \%$, respectively, by 2050 if the current technologies remain in use (which is unlikely). If irrigation water is guaranteed, then the output of three major cereal crops will be reduced less, by $2.2-6.7 \%, 0.4-11.9 \%$, and $4.3-12.4 \%$, respectively [62]. However, the supply of irrigation water cannot be guaranteed so the likely effect must be more pessimistic even with the positive effects of atmospheric $\mathrm{CO}_{2}$ fertilization [3]. Without adaptation, per capita cereal production is expected to fall in all cases by up to $40 \%$ of the current baseline (1961-1990) [63].

Analyses for Australia by Innes et al. [64] using a combination of experimental results coupled with simulation models have projected wheat yield reductions of $5.3 \%$ yield per $1{ }^{\circ} \mathrm{C}$. These are consistent with the global analysis by Fischer et al. and Asseng et al., but vary in different locations $[1,3]$. Wheat production occurs over much of the United States but predominantly occurs in the temperate regions of the southern Great Plains (Oklahoma and Kansas) to the northern Great Plains (North and South Dakota) and shows differing yield trends. Warming temperatures have already begun to decrease United States wheat yields in Kansas as observed by Tack et al. using historical yield and meteorological data [65]. Their regression analysis used a combination of freezing and warming impacts and revealed a $40 \%$ reduction in wheat yields with a $4{ }^{\circ} \mathrm{C}$ temperature increase and found the newer cultivars were less resistant to heat stress above $34^{\circ} \mathrm{C}$ than older cultivars, suggesting that selection of newer cultivars by producers to offset climate impacts may not be effective. In Oklahoma, 
yield has decreased by $45 \mathrm{~kg} \mathrm{ha}^{-1}$ year $^{-1}$ since 1998 while it has increased by $63 \mathrm{~kg} \mathrm{ha}^{-1} \mathrm{year}^{-1}$ in North Dakota. Differences in climate trends explain these yield responses, but a finer resolution of yield data at state or province level relative to climate is needed to better evaluate where changes in production will occur. For example, yields of winter and spring wheat in the Pacific Northwest states have undergone slight declines of less than $10 \mathrm{~kg} \mathrm{ha}^{-1}$ year $^{-1}$ since 1998, but based on crop models that incorporate effects of $\mathrm{CO}_{2}$ they are projected to increase or remain stable to 2090 under RCP 8.5, depending on specific locations, based on downscaled climate projections [66]. Asseng et al. projected an approximate $3 \%$ reduction in wheat yield per $1{ }^{\circ} \mathrm{C}$ increase in temperature for North America, notably less than the global average [3].

Continuing productivity of wheat and small grain systems under climate change requires attention to current cereal production regions so that new cultivar-management options can provide the basis for adaptation, but equally there is the issue of extending cereal production into regions that may become more climatically suited to these crops. At the same time, however, some current cereal production regions will likely be lost $[58,67]$. One recent study of transformational change (i.e., moving out of one crop or out of agriculture altogether) in Sub-Saharan Africa [68] suggests that three out of nine major food crops will be significantly affected. Under RCP 8.5 , maize and banana will have $~ 30 \%$ of their area transformed while for beans it is $>60 \%$. For maize, about $60 \%$ of the area will remain suitable and $40 \%$ requires transformation to millet or sorghum. Only a very small area, about $0.5 \%$ or 0.8 Mha, would have no substitute crops. Modelling together with experimentation plays a major role in understanding and managing such land use change, but while attention must be directed to individual locations, results from only a few representative locations may be misleading. Although crop modelling is an appropriate methodology for the analysis of the effects of climatic factors on crops, there are limitations related to the treatment of extreme temperature and the site specificity of many analyses. Despite the wide range of temperature environments where wheat and small grains are grown, current models lack adequate treatments of extreme temperature events such that more experimental work and model modification is a priority $[69,70]$. While the use of representative sites provides a practical scheme for analysis, many modelling examples are restricted to single sites. The validity of representative sites is still an issue of scale that the latest Agricultural Model Intercomparison and Improvement Project (AgMIP) is yet to address.

There are many challenges to overcome in the quest for increased crop productivity in individual regions. An important consequence of climate change for wheat production systems will be changes in land use. This is well-illustrated in the global study of Ray et al., in which future trends in crop yields were shown to stagnate, increase, plateau, or decline depending on location. For example, in Chile wheat is cropped from $35-40^{\circ} \mathrm{S}$ but projections suggest that it and other crops will contract southwards $\left(38-40^{\circ}\right)$ [71]. Changes in land use are also predicted in other countries by the main producers of maize, rice, and wheat. A lower grain yield of maize is expected, especially for northeast Brazil, and as a consequence a decrease in area sown to maize of $8.5-14 \%$ is projected for the whole country [47]. Positive changes are projected for rice in the southeast of South America (East of Argentina, Uruguay, and South of Brazil), where increases of grain yield up to $28 \%$ are predicted by using simulation models [72]. At present, soybean, maize, and wheat are the main crops sown in this area. One large Australian study [73] relied on modelling analyses from the town of Birchip to develop an expected response for the entire Victorian wheat belt. While that location can be considered typical of present day Victorian crop yields, the analysis did not consider the possibility of cropping moving to non-traditional cropping areas less than $200 \mathrm{~km}$ south near the city of Hamilton and the regional center of Warrnambool. A spatial analysis (100 m grid across Victoria) using a validated catchment wheat model [74] has shown a likely increase in wheat yield until 2070 in much of that region with adapted cultivars in contrast to yield decreases projected for Birchip by Anwar et al. [75]. While the spatial study of O'Leary et al. still attracts criticism because it shows potential yield increases outside the major wheat-growing regions of Victoria, it nevertheless shows the impact in response to adaptation of a potentially important trend [74]. 
Another important limitation of currently available methods is that field experiments and modelling analyses do not incorporate social, economic, regulatory, and administrative issues facing farmers and affecting farming practices. Farming combines crop and animal production within a complex socio-economic system such that proposals to advance the productivity of individual components must be tested on real farms under real conditions and the trade-offs understood [76]. While the need for this comprehensive assessment is acknowledged by research and farming organizations [77], the high cost and lack of funding make progress slow and fraught with potential failure. To compound the problem, there is a notable trend in developed countries for the general public and policymakers to undervalue science [78,79]. Without independent confirmation of our research, how can farmers be assured of success in adopting new practices? Present resources and investment into agricultural research in many developed countries, such as Australia and the USA, are inadequate for the task of meeting future global food demands [5,80]. More attention to the economic management of farming is needed because farmers in developed societies farm to meet economic objectives not for family food supply. However, even in developing countries where household food security is the priority, economic considerations are still key as farmers have limited capital to invest in technologies to increase yield. This points to a disconnect between the noble goals of increasing global food supplies and ensuring financial viability at the farm level.

While the call for more collaborative work is continually made, a more determined approach is needed [10,81-83]. Several studies from India are consistent with outputs from cropping system models [3] that project yield reductions of $10-40 \%$ by end of century unless adaption begins now, despite the beneficial effects of increased $\mathrm{CO}_{2}$ [84-87]. These studies do not include the effects of pests and diseases and changes in irrigation availability that could further impact crop production. The projected increase in drought and flood events in South Asia could result in greater instability in food production and threaten the livelihood of farmers. In general, most such studies assume no new technology development and no or limited adaptation by farmers. The situation may therefore be more positive if projections include progressive adaptation and smart-adaptive behaviour of farmers and other stakeholders.

Abundant literature is available for South Asia indicating technological, institutional, and policy interventions that can help farmers adapt to climate change as well as to current and future weather variability $[84,88]$. These include simple adaptation practices, such as changes in planting dates and crop cultivars. Additional strategies for increasing adaptive capacity include bridging yield gaps to augment production, deployment of weather tolerant cultivars and diversified land use systems, the use of solar power for irrigation, and assisting farmers in coping with current climatic risks with weather-linked value-added advisory services, crop/weather insurance, and improved land and water use management and policies.

It is also interesting to note that most of the proposed adaptation options include large mitigation co-benefits. The CGIAR's CCAFS program is scaling out the Climate-Smart Villages (CSVs) model in South Asia to promote a broader climate-smart agriculture [89]. These villages are sites where a portfolio of the most appropriate technological and institutional interventions, determined by the local community, are implemented to increase food production, enhance adaptive capacity, and reduce emissions. Interventions are customised to each village, but the concept lends itself to application in any region under individual circumstances. Initial results suggest a large potential to maximize synergies among different interventions. CSVs are also being implemented in East and West Africa with good opportunities for cross-regional learning [90].

Over the past few decades, national and regional governments have taken several policy and institutional initiatives to buffer agriculture from climatic risks. These include development and diffusion of adapted cultivars, development of contingency plans to manage region-specific risks, establishment of national food buffer stocks, crop insurance, and disaster relief. Although these initiatives have helped to reduce the impact of weather at an aggregated scale, significant problems persist at the local/regional level. To increase local benefits, a clear understanding is required of adaptation practices 
and technologies and the development of appropriate "business models". Crop insurance is one such strategy provided immediate benefits to local farmers are guaranteed. Simultaneous efforts are needed to address the complex problems of widespread poverty, poor governance, weak institutions, and human capital that have reduced the full potential of various adaptation practices. This is particularly true in Sub-Saharan Africa, where infrastructure is poor and policy and institutions are weak. Improvements in technologies, institutions, and policies in that region will play an important role into the future [91].

\section{Addressing the Challenges}

The idea that cropping systems will need adaptation as the climate changes is not new. The difficulties are, however, significant and complicated and can only be addressed once the complexity is reduced to manageable components by experimentation, analysis, and rational debate. While experiments involving field measurements and simulation modelling have foreshadowed significant declines in cereal grain yields across many regions of the world that grow cereals, positive impacts are also likely in many regions [5]. Positive benefits of adaptation are also predicted, offsetting expected declines in wheat, maize, and rice yield globally by $7-15 \%$ [92]. There is agreement across simulation, controlled environment, and field experiments that the grain yield of wheat is expected to decrease $5-6 \%{ }^{\circ} \mathrm{C}^{-1}$ despite including the additional benefits of $\mathrm{CO}_{2}$ fertilization $[3,11,93-95]$. There is, however, little information about the sensitivity of wheat during its various phenophases and the impact of projected higher night temperatures. In addition, the role of canopy temperature with and without water stress has been little explored, adding uncertainty to the projections made by simulation models. Without adaptation, typical yield declines by 2030 are projected at around $8 \%$ for wheat in the temperate regions of southern Australia [27]. Beyond 2030, greater losses around 12\% have been predicted.

Yield loss can potentially be offset by trends in annual yield gains due to breeding and agronomic practices at least to 2050 [1,5]. Furthermore, the effects of $\mathrm{CO}_{2}$ fertilization could be substantial. Inclusion of $\mathrm{CO}_{2}$ fertilization in crop models leads to projected increases in wheat yields for the Pacific Northwest of the USA well into the 21st century despite the negative effects of warming $[66,96]$. The yield gain measured in the Free-Air $\mathrm{CO}_{2}$ Enrichment (FACE) experiment at $550 \mathrm{ppm}$ (representing expected concentrations for 2050) at Horsham, Australia, was $25 \%$ and so exceeds the national projected losses to that date in the absence of fertilization (12\%) [97]. However, FACE experiments also have limitations because they measure response to $\mathrm{CO}_{2}$ without the temperature, precipitation, and vapour pressure differences of future climates. Other studies $[3,88]$ point to the need to consider all the interacting factors. An agronomic and genetic focus with a clear biophysical basis for crop adaptation is urgently needed [24,98].

Crop yield projections that include the possibility of changing geographical distribution are likely to counterbalance these somewhat pessimistic projections in which cropping systems retain their current distributions. One study [74] shows that as the climate warms and dries, yields could continue to increase until 2070 in the currently wetter parts of southern Australia. Whether production shifts occur, however, will depend on competition with other uses for land in these areas. The technical solutions that will reduce the impact of rising temperatures and reduced precipitation will involve a closer monitoring of soil water supplies and crop temperature and attention to crop sequences. For cropping in areas of higher precipitation, the management of pests and disease will likely be an added burden especially as the atmospheric $\mathrm{CO}_{2}$ levels rise. For example, Trebicki et al. found that under these conditions barley yellow dwarf virus will spread more quickly in infected wheat crops [99]. Globally, research on insect pests of wheat under climate change remains limited despite the potential of pests to reduce yields and increase yield variability [100].

The search is underway for stable and enduring crop traits and molecular markers to facilitate their incorporation into new cultivars, but needs support from improved models that better incorporate interactions between crop, genotype, and projected climatic conditions. Important traits include high water-use efficiency, heat tolerance (especially at flowering), greater carbohydrate reserves in the stems, and greater translocation of nutrients to the grain $[24,101,102]$. Traits from landraces that have 
been preserved in regions that are climate proxies for the future may also be useful. For example, sorghum and millet in West Africa incorporate adaptive traits from landraces or local/traditional cultivars, such as photoperiod sensitivity with high yield potential, which reduce yield losses and yield variability [58]. The use of new technology involving spatial management and large networks is expected. Existing international networks, such as the Expert Working Groups of the Wheat Initiative, might offer a conduit to help accelerate collaboration across the globe [103].

Improved genetics for adaptation to projected climate change must be accompanied by complementary production practices for both small holders and large-scale mechanized production. The Indian Climate-Smart Village (CSV) programme emphasizes five factors necessary to equip villages with skills to deal with the complexities of adapting to changing climate. They include water-smart practices (rainwater harvesting, laser land levelling, micro-irrigation, raised-bed planting, new crop establishment methods), weather-smart activities (ICT-based agro-advisories, index-based insurance, stress-tolerant crop cultivars), nutrient-smart practices (site-specific nutrient management, precision fertilizers, residue management, legume catch-cropping), carbon- and energy-smart practices (agroforestry, conservation tillage, residue management, legumes, livestock management), and knowledge-smart activities (farmer-to-farmer learning, capacity development, community seed banks and cooperatives, crop diversification, market information, and off-farm risk management). In developing countries with small-holder-based farming systems, implementing a CSV framework or similar approach requires integrated and ex-ante technological, institutional, and policy options [91]. In Sub-Saharan Africa, especially, current technologies are not widely adapted today due to myriad constraints. Access to information on management options, functional markets, and social and other support mechanisms are needed. For food-insecure farmers, livelihood diversification will be a key strategy and in many cases this may ultimately mean exiting agriculture.

These suites of practices in the CSV framework have their counterparts or equivalents for large-scale mechanized production that is predominant in North America, Australia, and large parts of South America. Integrated farming practices that consider present weather and soil conditions, such as precision fertilization, herbicide application, reduced tillage, remote sensing, and closer monitoring, are required [104].

A number of constraints have been identified. Some are technological, such as unrepresentative modelling sites, that can be overcome with more validation effort. Others are more problematic, such as an increasingly regulated environment that stifles new innovation [10]. Careful testing is required before new policies or technologies can be recommended for adoption. There are, however, some clear lessons from the past that that can form the basis for more rapid progress [105]. For example, in Australia, the importance of water to cropping is evident but its relationship with other environmental and socio-economic factors must be central to any adaptation strategy.

An important issue that arose in that Australian study was the identification of potential winners and losers with respect to future productivity. This will be true everywhere and benefits are not universal (e.g., in the Pacific Northwest USA [106]). One thought was that attention is most needed in the worst-affected regional areas (e.g., the north Western Australian grain belt as well as the wetter non-traditional cereal areas, e.g., the Victorian high precipitation Zone). An alternative view is to focus on the area with the greatest productive potential. However, both are best pursued simultaneously; the difficulty is to strike an acceptable balance because there is risk that untested practices may ultimately reduce productivity and contribute to increased social and economic unrest.

The features of the North and South American and Australian climates that range from sub-tropical to temperate with significant inter- and intra-season variability demand skilled management to be productive and efficient in the use of natural resources. This challenge extends beyond the farm unit, however, and impacts local communities in complex ways that invariably engage both local and central governments in financial and management assistance. Thus, research and implementation must be interdisciplinary [83]. The problem of a changing climate is not only one of biophysics and economics where the user is expected to pay for everything, but is also a market and social problem requiring the 
participation of all players. A renewed focus around the world offers hope that countries will keep ahead of the serious impacts of our variable and changing climate.

\section{The Global Perspective}

Significant agronomic and genetic advances have occurred across much of the global cereal dryland production areas despite their harsh and water-scarce environments. With a warmer and drier future climate projected for many places, more collaborative technological and socio-economic efforts are required, and the need will increase as the human population continues to grow. Temperature is an absolute boundary and water is scarce in much of the world's present grain-producing areas. The technological solutions should be built with the aim of increasing production by incremental advancement and with care not to reduce it. This requires:

1. Continued adaptation of crop cultivars

2. Continued application of new technology

3. More focus on nutrient sources, economy, efficiency, and sustainability

4. Management for weather extremes

5. Focus on grain quality while maintaining high productivity

6. Management of disease, pests, and weeds

7. Greater recycling and waste reduction

8. Building enduring partnerships, including with non-traditional collaborators

Technical solutions alone are insufficient to affect a sustained adaptation to a significantly different climatic environment. Other social, economic, and regulatory constraints will ultimately determine the course of adaptation and will need careful explanation and advocacy. More attention to the economic management of farming is needed because farmers in affluent societies farm for markets and economics and not their family food supply. This points to a disconnect between the noble goals of increasing global food supplies and remaining financially viable at the farm level. Can productivity be increased in the face of a changing climate? The conclusion of this paper is that it can, provided everybody and every organization support a stronger scientific approach by collaboration beyond our traditional partners and borders.

Acknowledgments: This work has been funded by the Australian Grains Research and Development Corporation, the Australian Government Department of Agriculture, the Victorian Department of Economic Development, Jobs, Transport and Resources, and the CGIAR Research Program on Climate Change, Agriculture and Food Security (CCAFS). Other significant collaboration has occurred with The University of Melbourne, CSIRO, The University of Florida, the USDA, and NASA in a world-wide crop model comparison and improvement project (AgMIP). The financial support of the University of Idaho and the USDA National Institute of Food and Agriculture (Award \#2011-680020-30191) for travel of GJO, PKA, DFC, PC, SDE, XH, and JLH to the Arid Cereals conference in the U.S. is gratefully acknowledged. The views and opinions expressed in this paper are those of the authors and not necessarily the views and opinions of the various agencies supporting the authors.

Author Contributions: S.D.E. conceived and facilitated the Arid Cereals conference where the component sections were presented and written up in this paper. G.J.O., P.K.A., D.F.C., D.J.C., P.C., S.D.E., X.H., and J.L.H. wrote their respective sections and contributed significantly to the general sections. G.J.O. coordinated the writing of the paper.

Conflicts of Interest: The authors declare no conflict of interest.

\section{Abbreviations}

AgMIP Agricultural Inter-Model comparison and Improvement Project

CCAFS Climate Change, Agriculture and Food Security

CERES Crop Environment Resource Synthesis

CGIAR Consultative Group on International Agricultural Research

CICS-NC Cooperative Institute for Climate and Satellites, North Carolina

CSV Climate-Smart Village 


$\begin{array}{ll}\text { FACE } & \text { Free Air } \mathrm{CO}_{2} \text { Enrichment } \\ \text { ICT } & \text { Information and communications technology } \\ \text { IPCC } & \text { Intergovernmental Panel on Climate Change } \\ \text { NASA } & \text { National Aero-Space Administration } \\ \text { NCDC } & \text { National Climate Data Center } \\ \text { NOAA } & \text { National Oceanic and Atmospheric Administration } \\ \text { PRECIS } & \text { Providing Regional Climates for Impacts Studies } \\ \text { RCP } & \text { Representative Concentration Pathway } \\ \text { SRES } & \text { Special Report on Emissions Scenarios } \\ \text { USDA } & \text { United States Department of Agriculture }\end{array}$

\section{References}

1. Fischer, R.A.; Byerlee, D.; Edmeades, G.O. Crop Yields and Global Food Security: Will Yield Increase Continue to Feed the World? ACIAR Monograph No. 158; Australian Centre for International Agricultural Research: Canberra, Australia, 2014; 634p.

2. Lobell, D.B.; Bänziger, M.; Magorokosho, C.; Vivek, B. Nonlinear heat effects on African maize as evidenced by historical yield trials. Nat. Clim. Change 2011, 1, 42-45. [CrossRef]

3. Asseng, S.; Ewert, F.; Martre, P.; Rötter, R.P.; Lobell, D.B.; Cammarano, D.; Kimball, B.A.; Ottman, M.J.; Wall, G.W.; White, J.W.; et al. Rising temperatures reduce global wheat production. Nat. Clim. Change 2015, 5, 143. [CrossRef]

4. Eastrerling, W.E. Chapter 14. Guidelines for Adapting Agriculture to Climate Change. In ICP Series on Climate Change Impacts, Adaption and Mitigation: Volume 1 Handbook of Climate Change and Agroecosystems: Impacts, Adaptation, and Mitigation; Hillel, D., Rozenzweig, C., Eds.; Imperial College Press: London, UK, 2011; pp. 269-286.

5. Cassman, K.G.; Grassini, P.; van Wart, J. Crop yield potential, yield trends, and global food security in a changing climate. In Handbook of Climate Change and Agroecosystems; Rosenzweig, C., Hillel, D., Eds.; Imperial College Press: London, UK, 2011; pp. 37-51.

6. Foley, J.A.; Ramankutty, N.; Brauman, K.A.; Cassidy, E.S.; Gerber, J.S.; Johnston, M.; Mueller, N.D.; O'Connell, C.; Ray, D.K.; West, P.C.; et al. Solutions for a cultivated planet. Nature 2011, 478, 337-342. [CrossRef] [PubMed]

7. Rickards, L.; Howden, S.M. Transformational adaptation: Agriculture and climate change. Crop Pasture Sci. 2012, 63, 240-250. [CrossRef]

8. Richards, R.A.; Hunt, J.R.; Kirkegaard, J.A.; Passioura, J.B. Yield improvement and adaptation of wheat to water-limited environments in Australia-A case study. Crop Pasture Sci. 2014, 65, 676-689.

9. Connor, D.J.; Mínguez, I.M. Evolution not revolution of farming systems will best feed and green the world. Glob. Food Sec. 2012, 1, 106-113. [CrossRef]

10. Hall, A.J.; Richards, R.A. Prognosis for genetic improvement of yield potential and water-limited yield of major grain crops. Field Crops Res. 2013, 143, 18-33. [CrossRef]

11. Liu, B.; Asseng, S.; Müller, C.; Ewert, F.; Elliott, J.; Lobell, D.; Martre, P.; Ruane, A.; Wallach, D.; Jones, J.W.; et al. Similar estimates of temperature impacts on global wheat yield by three independent methods. Nat. Clim. Change 2016, 6, 1130-1138. [CrossRef]

12. Ray, D.K.; Gerber, J.S.; MacDonald, G.K.; West, P.C. Climate variation explains a third of global crop yield variability. Nat. Commun. 2015, 6, 5989. [CrossRef] [PubMed]

13. Osborne, T.M.; Wheeler, T.R. Evidence for a climate signal in trends of global crop yield variability over the past 50 years. Environ. Res. Lett. 2013, 8, 024001. [CrossRef]

14. Toreti, A.; Naveau, P.; Zampieri, M.; Schindler, A.; Scoccimarro, E.; Xoplaki, E.; Dijkstra, H.A.; Gualdi, S.; Luterbacher, J. Projections of global changes in precipitation extremes from Coupled Model Intercomparison Project Phase 5 models. Geophys. Res. Lett. 2013. [CrossRef]

15. Fischer, E.M.; Knutti, R. Anthropogenic contribution to global occurrence of heavy-precipitation and high-temperature extremes. Nat. Clim. Change 2015, 5, 560-564. [CrossRef] 
16. Kitoha, A.; Endob, H. Changes in precipitation extremes projected by a $20-\mathrm{km}$ mesh global atmospheric model. Weather Clim. Extremes 2016, 11, 41-52. [CrossRef]

17. Connor, D.J.; Loomis, R.S.; Cassman, K.G. Crop Ecology. Production and Management in Agricultural Systems; CUP: Cambridge, UK, 2011.

18. Sinclair, T.R. Chapter 9. Precipitation: The Thousand-Pound Gorilla in Crop Response to Climate Change. In ICP Series on Climate Change Impacts, Adaption and Mitigation: Volume 1 Handbook of Climate Change and Agroecosystems: Impacts, Adaptation, and Mitigation; Hillel, D., Rozenzweig, C., Eds.; Imperial College Press: London, UK, 2011; pp. 179-190.

19. Fischer, R.A. Growth and water limitation to dryland wheat yield: A physiological framework. J. Aust. Inst. Agric. Sci. 1979, 45, 83-94.

20. O'Leary, G.J.; Connor, D.J.; White, D.H. A simulation model of the development, growth and yield of the wheat crop. Agric. Syst. 1985, 17, 1-26. [CrossRef]

21. van Herwaarden, A.F.; Farquhar, G.D.; Angus, J.F.; Richards, R.A.; Howe, G.N. 'Haying-off', the negative grain yield response of dryland wheat to nitrogen fertiliser I. Biomass, grain yield, and water use. Aust. J. Agric. Res. 1998, 49, 1067-1081. [CrossRef]

22. Nuttall, J.G.; O'Leary, G.J.; Khimashia, N.; Asseng, S.; Fitzgerald, G.; Norton, R. 'Haying-off' in wheat is predicted to increase under a future climate in south-eastern Australia. Crop Pasture Sci. 2012, 63, 593-605. [CrossRef]

23. Rebbeck, M.A.; Knell, G.R. Managing Frost Risk. A Guide for Southern Australian Grains. 2007. Available online: https://grdc.com.au/resources-and-publications/all-publications/bookshop/2007/06/ managing-frost-risk-a-guide-for-southern-australian-grains (accessed on 1 March 2018).

24. Cairns, J.E.; Sonder, K.; Zaidi, P.H.; Verhulst, N.; Mahuku, G.; Babu, R.; Nair, S.K.; Das, B.; Govaerts, B.; Vinayan, M.T.; et al. Maize Production in a Changing Climate: Impacts, Adaptation and Mitigation Strategies. Adv. Agron. 2012, 114, 1-58.

25. Porter, J.R.; Gawith, M. Temperatures and the growth and development of wheat: A review. Eur. J. Agron. 1999, 10, 23-36. [CrossRef]

26. Nicholls, N. The changing nature of Australian droughts. Clim. Change 2004, 63, 323-336. [CrossRef]

27. Bureau of Meteorology, Melbourne Australia. Available online: http://www.bom.gov.au (accessed on 1 March 2018).

28. Power, S.; Tseitkin, F.; Torok, S.; Lavery, B.; Dahni, R.; McAvaney, B. Australian temperature, Australian rainfall and the Southern Oscillation, 1910-1992: Coherent variability and recent changes. Aust. Meteorol. Mag. 1998, 47, 85-101.

29. Power, S.; Casey, C.; Folland, C.; Mehta, V. Inter-decadel modulation of the impact of ENSO on Australia. Clim. Dyn. 1999, 15, 319-324. [CrossRef]

30. Potgieter, A.B.; Hammer, G.L.; Butler, D. Spatial and temporal patterns in Australian wheat yield and their relationship with ENSO. Aust. J. Agric. Res. 2002, 53, 77-89. [CrossRef]

31. Rimmington, G.M.; Nicholls, N. Forecasting wheat yields in Australia with the Southern Oscillation Index. Aust. J. Agric. Res. 1993, 44, 625-632. [CrossRef]

32. Anwar, M.R.; Rodriguez, D.; Liu, D.L.; Power, S.; O'Leary, G.J. Quality and potential utility of ENSO-based forecasts of spring rainfall and wheat yield in south eastern Australia. Aust. J. Agric. Res. 2008, 59, 1-15. [CrossRef]

33. Wang, S.W.; Ye, J.L.; Gong, D.Y.; Zhu, J.H. Construction of mean annual temperature series for the last one hundred years in China. Q. J. Appl. Meteorol. 1998, 9, 392-401. (In Chinese)

34. Lin, X.C.; Yu, S.Q.; Tang, G.L. Series of average air temperature over China for the last 100-year period. Sci. Atoms. Sin. 1995, 19, 525-534. (In Chinese)

35. Tang, G.L.; Ren, G.Y. Reanalysis of surface air temperature change of the last 100 years over China. Clim. Environ. Res. 2005, 10, 791-798. (In Chinese)

36. Wen, X.Y.; Wang, S.W.; Zhu, J.H.; Viner, D. An overview of China climate change over the 20th century using UK UEA/CRU high resolution grid data. Chin. J. Atmos. Sci. 2006, 30, 894-904. (In Chinese)

37. Cao, L.J.; Zhao, P.; Yan, Z.W.; Jones, P.; Zhu, Y.N.; Yu, Y.; Tang, G.L. Instrumental temperature series in eastern and central China back to the nineteenth century. Atmospheres 2013, 118, 8197-8207. [CrossRef]

38. Committee of Assessment Report of National Climate Change. The 3rd Assessment Report of National Climate Change; Science Press: Beijing, China, 2015. (In Chinese) 
39. Rathore, L.S.; Attri, S.D.; Jaswal, A.K. State Level Climate Change Trends in India; India Meteorological Department, Ministry of Earth Sciences, Government of India: New Delhi, India, 2013; p. 147.

40. Jain, S.K.; Kumar, V. Trend analysis of rainfall and temperature data for India-A Review. Curr. Sci. 2012, 102, 37-49.

41. Singh, D.; Tsiang, M.; Rajaratnam, B.; Diffenbaugh, N. Observed changes in extreme wet and dry spells during the South Asian summer monsoon season. Nat. Clim. Change 2014, 4, 456-461. [CrossRef]

42. Intergovernmental Panel on Climate Change (IPCC). Technical summary. In Climate Change 2013: The Physical Science Basis. Contribution of Working Group I to the Fifth Assessment Report of the Intergovernmental Panel on Climate Change; Stocker, T.F., Qin, D., Plattner, G.-K., Tignor, M., Allen, S.K., Boschung, J., Nauels, A., Xia, Y., Bex, V., Midgley, P.M., Eds.; Cambridge University Press: Cambridge, UK; New York, NY, USA, 2013.

43. Dixon, J.; Gibbon, D. Farming Systems and Poverty_Improving Famers' Livelihoods in a Changing World; FAO and World Bank: Rome, Italy; Washington, DC, USA, 2001.

44. Intergovernmental Panel on Climate Change (IPCC). Part A: Global and Sectoral Aspects. In Climate Change 2014: Impacts, Adaptation, and Vulnerability. Contribution of Working Group II to the Fifth Assessment Report of the Intergovernmental Panel on Climate Change; Field, C.B., Barros, V.R., Dokken, D.J., Mach, K.J., Mastrandrea, M.D., Bilir, T.E., Chatterjee, M., Ebi, K.L., Estrada, Y.O., Genova, R.C., et al., Eds.; Cambridge University Press: Cambridge, UK; New York, NY, USA, 2014; Chapter 22; p. 115.

45. Osbahr, H.; Dorward, P.; Stern, R.; Cooper, S. Supporting agricultural innovation in Uganda to respond to climate risk: Linking climate change and variability with farmer perceptions. Expl. Agric. 2011, 47, $293-316$. [CrossRef]

46. Walsh, J.; Wuebbles, D.; Hayhoe, K.; Kossin, J.; Kunkel, K.; Stephens, G.; Thorne, P.; Vose, R.; Wehner, M.; Willis, J.; et al. Chapter 2: Our Changing Climate. In Climate Change Impacts in the United States: The Third National Climate Assessment 2014; Melillo, J.M., Richmond, T.T.C., Yohe, G.W., Eds.; U.S. Global Change Research Program: Washington, DC, USA, 2014; pp. 19-67.

47. Magrin, G.O.; Marengo, J.A.; Boulanger, J.P.; Buckeridge, M.S.; Castellanos, E.; Poveda, G.; Scarano, F.R.; Vicuña, S.; Central and South America. Part B: Regional Aspects. In Climate Change 2014: Impacts, Adaptation, and Vulnerability. Contribution of Working Group II to the Fifth Assessment Report of the Intergovernmental Panel on Climate Change; Barros, V.R., Field, C.B., Dokken, D.J., Mastrandrea, M.D., Mach, K.J., Bilir, T.E., Chatterjee, M., Ebi, K.L., Estrada, Y.O., Genova, R.C., et al., Eds.; Cambridge University Press: Cambridge, UK; New York, NY, USA, 2014; pp. 1499-1566.

48. Rusticucci, M. Observed and simulated variability of extreme temperature events over South America. Atmos. Res. 2012, 106, 1-17. [CrossRef]

49. Lavado, C.W.S.; Ronchail, J.; Labat, D.; Espinoza, J.C.; Guyot, J.L. Basin-scale analysis of rainfall and runoff in Peru (1969-2004): Pacific, Titicaca and Amazonas drainages. Hydrol. Sci. J. 2012, 57, 625-642. [CrossRef]

50. Hannah, M.C.; O'Leary, G.J. Wheat yield response to rainfall in a long-term multi-rotation experiment in the Victorian Wimmera. Aust. J. Exp. Agric. 1995, 35, 951-960. [CrossRef]

51. Connor, D.J. Designing cropping systems for efficient use of limited water in southern Australia. Eur. J. Agron. 2004, 21, 419-431. [CrossRef]

52. Zhang, Z.B.; Duan, Z.Y.; Chen, Z.B.; Xu, P.; Li, G.Q. Food security of China: The past, present and future. Plant Omics 2010, 3, 183-189.

53. Rozelle, S.; Huang, J. Transition, development and the supply of wheat in China. Aust. J. Agric. Res. Econ. 2000, 44, 543-571. [CrossRef]

54. Tao, F.L.; Zhang, Z.; Zhang, S.; Zhu, Z.; Shi, W.J. Response of crop yields to climate trends since 1980 in China. Clim. Res. 2012, 54, 233-247. [CrossRef]

55. Food and Agriculture Office Statistics (FAOSTAT). Available online: http:// faostat3.fao.org (accessed on 1 March 2018).

56. United States Department of Agricultural National Agricultural Statistics Service (NASS). Available online: http:/ / www.nass.usda.gov (accessed on 1 March 2018).

57. Ekboir, J.; Parellada, G. Public-private interactions and technology policy in innovation processes for zero tillage in Argentina. In Agricultural Research Policy in an Era of Privatization; Byerlee, D., Echeverría, R., Eds.; CABI Publishing: Wallingford, CT, USA, 2002; pp. 137-154. 
58. Sultan, B.; Roudier, P.; Quirion, P.; Alhassane, A.; Muller, B.; Dingkuhn, M.; Ciais, P.; Guimberteau, M.; Traore, S.; Baron, C. Assessing climate change impacts on sorghum and millet yields in the Sudanian and Sahelian savannas of West Africa. Environ. Res. Lett. 2013, 8, 014040. [CrossRef]

59. Tesfaye, K.; Gbegbelegbe, S.; Cairns, J.E.; Shiferaw, B.; Prasanna, B.M.; Sonder, K.; Boote, K.; Makumbi, D.; Robertson, R. Maize systems under climate change in sub-Saharan Africa: Potential impacts on production and food security. Int. J. Clim. Change Strat. Manag. 2015, 7, 247-271. [CrossRef]

60. Giorgi, F.; Diffenbaugh, N. Developing regional climate change scenarios for use in assessment of effects on human health and disease. Clim. Res. 2008, 36, 141-151. [CrossRef]

61. Marengo, J.A.; Ambrizzi, T.; da Rocha, R.; Alves, L.; Cuadra, S.; Valverde, M.; Torres, R.; Santos, D.; Ferraz, S. Future change of climate in South America in the late twenty-first century: Intercomparison of scenarios from three regional climate models. Clim. Dyn. 2010, 35, 1073-1097. [CrossRef]

62. Lin, E.; Xiong, W.; Ju, H.; Xu, Y.L.; Li, Y.; Bai, L.P.; Xie, L.Y. Climate change impacts on crop yield and quality with $\mathrm{CO}_{2}$ fertilization in China. Philos. Trans. R. Soc. Lond. 2005, 360, 2149-2155.

63. Xiong, W.; Conway, D.; Lin, E.; Xu, Y.L.; Ju, H.; Jiang, J.H.; Holman, I.; Li, F. Future cereal production in China: The interaction of climate change, water availability and socio-economic scenarios. Glob. Environ. Change 2009, 19, 34-44. [CrossRef]

64. Innes, P.J.; Tan, D.K.Y.; van Ogtrop, F.; Amthor, J.S. Effects of high temperature episodes on wheat yields in New South Wales, Australia. Agric. For. Meteorol. 2015, 208, 95-107. [CrossRef]

65. Tack, J.; Barkley, A.; Nalley, L.L. Effect of warming temperatures on US wheat yields. Proc. Natl. Acad. Sci. USA. 2015, 112, 6931-6936. [CrossRef] [PubMed]

66. Stöckle, C.; Higgins, S.; Nelson, R.; Abatzoglou, J.; Huggins, D.; Pan, W.; Karimi, T.; Antle, J.; Eigenbrode, S.D.; Brooks, E. Evaluating opportunities for an increased role of winter crops as adaptation to climate change in dryland cropping systems of the U.S. Inland Pacific Northwest. Clim. Change 2017. [CrossRef]

67. Wang, B.; Liu, D.L.; O’Leary, G.J.; Asseng, S.; Macadam, I.; Lines-Kelly, R.; Yang, X.; Clark, A.; Crean, J.; Sides, T.; et al. Australian wheat production expected to decrease by the late 21st century. Glob. Change Biol. 2018. [CrossRef] [PubMed]

68. Rippke, U.; Ramirez-Villegas, J.; Jarvis, J.; Vermeulen, S.J.; Parker, L.; Mer, F.; Diekkrüger, B.; Challinor, A.J.; Howden, M. Timescales of transformational climate change adaptation in sub-Saharan African agriculture. Nat. Clim. Change 2016, 6, 605-610. [CrossRef]

69. Barlow, K.M.; Christy, B.P.; O’Leary, G.J.; Riffkin, P.A.; Nuttall, J.G. Simulating the impact of extreme heat and frost events on wheat crop production: A review. Field Crops Res. 2015, 171, 109-119. [CrossRef]

70. Lobell, D.B.; Hammer, G.L.; Chenu, K.; Zheng, B.; McLean, G.; Chapman, S.C. The shifting influence of drought and heat stress for crops in Northeast Australia. Glob. Change Biol. 2015. [CrossRef] [PubMed]

71. Ray, D.K.; Ramankutty, N.; Muller, N.D.; West, P.C.; Foley, J.A. Recent patterns of crop yield growth and stagnation. Nat. Commun. 2012, 3, 1293. [CrossRef] [PubMed]

72. Walter, L.C.; Rosa, H.T.; Streck, N.A. Simulação do rendimento de grãos de arroz irrigado em cenários de mudanças climáticas [Simulating grain yield of irrigated rice in climate change scenarios]. Pesqui. Agropecu. Brasil. 2010, 45, 1237-1245. [CrossRef]

73. Crimp, S.; Howden, M.; Power, B.; Wang, E.; De Voil, P. Global Climate Change Impacts on Australia's Wheat Crops, Report Prepared for the Garnaut Climate Change Review; CSIRO: Canberra, Australia, 2008.

74. O'Leary, G.; Christy, B.; Weeks, A.; Nuttall, J.; Riffkin, P.; Beverly, C.; Fitzgerald, G. Chapter 1.2. Downscaling Global Climatic Predictions to the Regional Level: A Case Study of Regional Effects of Climate Change on Wheat Crop Production in Victoria, Australia. In Crop Adaptation to Climate Change, 1st ed.; Yadav, S.S., Redden, R.J., Hatfield, J.L., Lotze-Campen, H., Hall, A.E., Eds.; John Wiley \& Sons, Ltd.: Chichester, West Sussex, UK, 2011; pp. 12-26. ISBN 978-0-8138-2016-3.

75. Anwar, M.; O’Leary, G.; McNeil, D.; Hossain, H.; Nelson, R. Climate change impact on wheat crop yield and adaptation options in Southeastern Australia. Field Crops Res. 2007, 104, 139-147. [CrossRef]

76. Claessens, L.; Antle, J.M.; Stoorvogel, J.J.; Valdivia, R.O.; Thornton, P.K.; Herrero, M. A method for evaluating climate change adaptation strategies for small-scale farmers using survey, experimental and modeled data. Agric. Syst. 2012, 111, 85-95. [CrossRef]

77. Grains Research and Development Corporation (GRDC). RDEE Strategy for the Grains Industry; Version 1.2 15 April 2015; Grains Research and Development Corporation: Canberra, Australia, 2014; p. 84. ISBN 978-1-921779-66-4. 
78. Gauchat, G. Politicization of Science in the Public Sphere-A Study of Public Trust in the United States, 1974 to 2010. Am. Sociol. Rev. 2012, 77, 2167-2187. [CrossRef]

79. Hopkins, R. Unbelievable: Why Americans Mistrust Science. SciBytes. May 2014. Available online: http:/ / www.nature.com/scitable/blog/scibytes/unbelievable (accessed on 19 March 2018).

80. Cribb, J. The Coming Famine. The Global Food Crisis and What We Can Do to Avoid It; CSIRO Publishing: Melbourne, Australia, 2010; 264p, ISBN 9780643100404.

81. Redden, R.J.; Hatfield, J.L.; Vara Prasad, P.V.; Ebert, A.W.; Yadav, S.S.; O’Leary, G.J. Chapter 8. Temperature, climate change, and global food security. In Temperature and Plant Development; Franklin, K., Wigge, P., Eds.; John Wiley \& Sons, Inc.: Oxford, UK, 2014.

82. Reynolds, M.P.; Quilligan, E.; Aggarwal, P.K.; Bansal, K.C.; Cavalieri, A.J.; Chapman, S.C.; Chapotin, S.M.; Datta, S.K.; Duveiller, E.; Gill, K.S.; et al. An integrated approach to maintaining cereal productivity under Climate change. Glob. Food Sec. 2016, 8, 9-18. [CrossRef]

83. Eigenbrode, S.D.; Binns, W.P.; Huggins, D.R. Confronting climate change challenges to dryland cereal production: A call for collaborative, transdisciplinary research, and producer engagement. Front. Ecol. Evol. 2018, 5, 164. [CrossRef]

84. Aggarwal, P.K. (Ed.) Global Climate Change and Indian Agriculture. Case Studies from the ICAR Network Project; Indian Council of Agricultural Research: New Delhi, India, 2009; 148p.

85. Knox, J.W.; Hess, T.M.; Daccache, A.; Perez Ortola, M. What are the Projected Impacts of Climate Change on Food Crop Productivity in Africa and South Asia? DFID Systematic Review, Final Report; Cranfield University: Bedford, UK, 2011; p. 77.

86. Kattarkandi, B.; Naresh Kumar, S.; Aggarwal, P.K. Simulating impacts, potential adaptation and vulnerability of maize to climate change in India. Mitig. Adapt. Strateg. Glob. Change 2010, 15, 413-431.

87. Srivastava, A.; Kumar, S.N.; Aggarwal, P.K. Assessment on vulnerability of sorghum to climate change in India. Agric. Ecosys. Environ. 2010, 38, 160-169. [CrossRef]

88. Aggarwal, P.K.; Sivakumar, M.V.K. Global Climate Change and Food Security in South Asia: An Adaptation and Mitigation Framework. In Climate Change and Food Security in South Asia; Lal, R., Sivakumar, M.V.K., Faiz, S.M.A., Mustafizur Rahman, A.H.M., Islam, K.R., Eds.; Springer: Berlin, Germany, 2010; pp. $253-275$.

89. Climate Change, Agriculture and Food Security (CCAFS). Available online: https://ccafs.cgiar.org (accessed on 1 March 2018).

90. Wood, S.; Jina, A.S.; Jain, M.; Kristjanson, P.; DeFries, R.S. Smallholder cropping decisions related to climate variability across multiple regions. Glob. Environ. Change 2014, 25, 163-172. [CrossRef]

91. Shiferaw, B.; Tesfaye, K.; Kassie, M.; Abate, T.; Prasanna, B.M.; Menkir, A. Managing vulnerability to drought and enhancing livelihood resilience in sub-Saharan Africa: Technological, institutional and policy options. Weather Clim. Extremes 2014, 3, 67-79. [CrossRef]

92. Challinor, A.; Watson, J.; Lobell, D.B.; Howden, S.M.; Smith, D.R.; Chhetri, N. A meta-analysis of crop yield under climate change and adaptation. Nat. Clim. Change 2014, 4, 287-291. [CrossRef]

93. Prasad, P.V.V.; Pisipati, S.R.; Ristic, Z.; Bukovnik, U.; Fritz, A.K. Impact of nighttime temperature on physiology and growth of spring wheat. Crop Sci. 2008, 48, 2372-2380. [CrossRef]

94. Lizana, X.C.; Calderini, D.F. Yield and grain quality of wheat in response to increased temperatures at key periods for grain number and grain weight determination: Considerations for the climatic change scenarios of Chile. J. Agric. Sci. 2013, 151, 209-221. [CrossRef]

95. Garcia, G.A.; Dreccer, M.F.; Miralles, D.J.; Serrago, R.A. High night temperatures during grain number determination reduce wheat and barley grain yield: A field study. Glob. Change Biol. 2015, 2, 4153-4164. [CrossRef] [PubMed]

96. Stöckle, C.O.; Nelson, R.L.; Higgins, S.; Brunner, J.; Grove, G.; Boydston, R.; Whiting, M.; Kruger, C. Assessment of climate change impact on Eastern Washington agriculture. Clim. Change 2010, 102, 77-102. [CrossRef]

97. O’Leary, G.J.; Christy, B.; Nuttall, J.; Huth, N.; Cammarano, D.; Stöckle, C.; Basso, B.; Shcherbak, I.; Fitzgerald, G.; Luo, Q.; et al. Response of wheat growth, grain yield and water use to elevated $\mathrm{CO}_{2}$ under a Free Air $\mathrm{CO}_{2}$ Enrichment (FACE) experiment and modelling in a semi-arid environment. Glob. Change Biol. 2015. [CrossRef] [PubMed]

98. Sadras, V.; Dreccer, F. Adaptation of wheat, barley, canola, pea and chickpea to the thermal environments of Australia. Crop Pasture Sci. 2015, 66, 1137-1150. [CrossRef] 
99. Trebicki, P.; Nancarrow, N.; Cole, E.; Bosque-Perez, N.A.; Constable, F.E.; Freeman, A.J.; Rodoni, B.; Yen, A.L.; Luck, J.E.; Fitzgerald, G.J. Virus disease in wheat predicted to increase with a changing climate. Glob. Change Biol. 2015, 21, 3511-3519. [CrossRef] [PubMed]

100. Eigenbrode, S.D.; Macfadyen, S. The impact of climate change on wheat insect pests: current knowledge and future trends. In Achieving Sustainable Cultivation of Wheat, Volume 1: Breeding, Quality traits, Pests and Diseases; Langridge, P., Ed.; Burleigh Dodds Science Publishing: Cambridge, UK, 2017; pp. 545-567.

101. Fernando, N.; Panozzo, J.; Tausz, M.; Norton, R.M.; Nuemann, N.; Fitzgerald, G.J.; Seneweera, S. Elevated $\mathrm{CO}_{2}$ alters grain quality of two bread wheat cultivars grown under different environmental conditions. Agric. Ecosyst. Environ. 2014, 185, 24-33. [CrossRef]

102. Panozzo, J.F.; Walker, C.K.; Partington, D.L.; Neumann, N.C.; Tausz, M.; Seneweera, S.; Fitzgerald, G.J. Elevated carbon dioxide changes grain protein concentration and composition and compromises baking quality. A FACE study. J. Cereal Sci. 2014, 60, 461-470. [CrossRef]

103. Expert Working Group on the Wheat Initiative. Available online: http://www.wheatinitiative.org/ (accessed on 1 March 2018).

104. Llewellyn, R.S.; Ronning, D.; Ouzman, J.; Walker, S.; Mayfield, A.; Clarke, M. Impact of Weeds on Australian Grain Production: The Cost of Weeds to Australian Grain Growers and the Adoption of Weed Management and Tillage Practices; Report for GRDC; CSIRO: Canberra, Australia, 2016; Available online: https:/ /grdc.com.au/ resources-and-publications/all-publications/bookshop (accessed on 1 March 2018).

105. Sprigg, H.; Belford, R.; Milroy, S.; Bennett, S.J.; Bowran, D. Adaptations for growing wheat in the drying climate of Western Australia. Crop and Past. Sci. 2014, 65, 627-644. [CrossRef]

106. Antle, J.M.; Mu, J.E.; Zhang, H.; Capalbo, S.M.; Diebel, P.L.; Eigenbrode, S.D.; Kruger, C.E.; Stockle, C.O.; Wulfhorst, J.; Abatzoglou, J.T. Design and use of representative agricultural pathways for integrated assessment of climate change in U.S. Pacific Northwest cereal-based systems. Front. Ecol. Evol. 2017, 5, 99. [CrossRef]

(C) 2018 by the authors. Licensee MDPI, Basel, Switzerland. This article is an open access article distributed under the terms and conditions of the Creative Commons Attribution (CC BY) license (http:/ / creativecommons.org/licenses/by/4.0/). 